\title{
Milk production of Holstein-Friesian cows of divergent Economic Breeding Index evaluated under seasonal pasture-based management
}

\author{
M. O’Sullivan, ${ }^{1,2}$ B. Horan, ${ }^{1}$ K. M. Pierce, ${ }^{2}$ S. McParland, ${ }^{1}$ K. O'Sullivan, ${ }^{3}$ and F. Buckley ${ }^{1,2 *}$ \\ ${ }^{1}$ Animal and Grassland Research and Innovation Centre, Teagasc Moorepark, Fermoy, Co. Cork, P61 C997 Ireland \\ ${ }^{2}$ School of Agriculture and Food Science, University College Dublin, Belfield, Dublin, D04 N2E5 Ireland \\ ${ }^{3}$ School of Mathematical Sciences, University College Cork, Cork, T12 XF62 Ireland
}

\section{ABSTRACT}

The objective of this study was to validate the effect of genetic improvement using the Irish genetic merit index, the Economic Breeding Index (EBI), on total lactation performance and lactation profiles for milk yield, milk solids yield (fat plus protein; $\mathrm{kg}$ ), and milk fat, protein, and lactose content within 3 pasture-based feeding treatments (FT) and to investigate whether an interaction exists between genetic group (GG) of Holstein-Friesian and pasture-based FT. The 2 GG were (1) extremely high EBI representative of the top $5 \%$ nationally (referred to as the elite group) and (2) representative of the national average EBI (referred to as the NA group). Cows from each GG were randomly allocated each year to 1 of 3 pasture-based FT: control, lower grass allowance, and high concentrate. The effects of GG, FT, year, parity, and the interaction between GG and FT adjusted for calving day of year on milk and milk solids (fat plus protein; $\mathrm{kg}$ ) production across lactation were studied using mixed models. Cow was nested within GG to account for repeated cow records across years. The overall and stage of lactationspecific responses to concentrate supplementation (high concentrate vs. control) and reduced pasture allowance (lower grass allowance vs. control) were tested. Profiles of daily milk yield, milk solids yield, and milk fat, protein, and lactose content for each week of lactation for the elite and NA groups within each FT and for each parity group within the elite and NA groups were generated. Phenotypic performance was regressed against individual cow genetic potential based on predicted transmitting ability. The NA cows produced the highest milk yield. Milk fat and protein content was higher for the elite group and consequently yield of solids-corrected milk was similar, whereas yield of milk solids tended to be higher for the elite group com-

Received August 21, 2018.

Accepted November 7, 2018.

*Corresponding author: Frank.Buckley@teagasc.ie pared with the NA group. Milk lactose content did not differ between GG. Responses to concentrate supplementation or reduced pasture allowance did not differ between GG. Milk production profiles illustrated that elite cows maintained higher production but with lower persistency than NA cows. Regression of phenotypic performance against predicted transmitting ability illustrated that performance was broadly in line with expectation. The results illustrate that the superiority of high-EBI cattle is consistent across diverse pasturebased FT. The results also highlight the success of the EBI to deliver production performance in line with the national breeding objective: lower milk volume with higher fat and protein content.

Key words: dairy cow, Economic Breeding Index, Holstein-Friesian, milk solids

\section{INTRODUCTION}

Milk production in Ireland is primarily based on seasonal calving pasture-based systems, characterized by lower production costs (Dillon et al., 2008). Grazed grass is the lowest cost feed available, and the objective of the system is to optimize its use in the diet of the lactating dairy cow (Dillon et al., 1995). Grazing systems represent a minority of global milk production (Steinfeld and Mäki-Hokkonen, 1995), and the biological and financial efficiency of milk production in such systems is uniquely dependent on an integrated seasonal production model (Coffey et al., 2016) in which mutual compatibility between the cow and the system is important (Delaby et al., 2018). Optimization of the system depends on a cow that can efficiently convert grass to a high-quality milk product (Horan et al., 2005b; Washburn and Mullen, 2014), with the exportorientated market for Ireland's largely commoditybased product portfolio dictating a requirement among milk processors for milk with high milk fat and protein content (Geary et al., 2010).

Since 2001, in response to observations by Buckley et al. (2000a) and Snijders et al. (2001) and in consonance with developments in selection indices globally (Miglior 
et al., 2005), trait emphasis in dairy cattle breeding in Ireland has shifted from a milk production-based index, the Relative Breeding Index, to the profit-based Economic Breeding Index (EBI; Veerkamp et al., 2002) to identify appropriate genetics for Irish grazing systems. The EBI initially comprised 2 subindices but now comprises 7 subindices incorporating 19 traits. Desirable characteristics for optimum performance in pasture-based systems are highlighted by Buckley et al. (2005) and corroborated by the findings of Horan et al. (2005a) and McCarthy et al. (2007), who evaluated contrasting strains of Holstein-Friesian (HF) cows. The establishment of the G€N€ IR€LAND national dairy breeding program in 2005 (Kearney et al., 2018) facilitated progeny testing of indigenously sourced genetics for Irish grazing systems. Genomic selection (Meuwissen et al., 2001) has led to a considerable change in breeding scheme design worldwide (Spelman et al., 2013), with a shift from progeny testing to DNA testing of bulls, leading to a shortening of generation intervals and more rapid genetic gain. Genomics technology was first implemented in Ireland in 2009 (Wickham et al., 2012), with Ireland becoming the second country globally to adopt genomic selection into the national genetic evaluations. The EBI of available genomically selected bulls has consistently been 1 genetic standard deviation greater than the EBI of proven bulls (Spelman et al., 2013), with genomically selected bull semen accounting for $40 \%$ of dairy semen sales in Ireland in 2010 (Wickham et al., 2012) and increasing to $70 \%$ by 2016 (ICBF, 2016a).

Higher EBI has been shown to be associated with increased milk solids production (Coleman et al., 2010) and herd profitability (Ramsbottom et al., 2012). However, rapid rates of theoretical genetic gain (ICBF, 2018b) and lessons learned from the past (Buckley et al., 2000b; Snijders et al., 2001; Evans et al., 2002) suggest that periodic re-evaluation of breeding goals is prudent to validate genetic gain and ensure the compatibility of resultant genetics with the production system. For instance, little is known of the lactation profiles, the response of animals selected on EBI to varying levels of feeding management, and the extent to which milk production performance of cows varying in EBI is influenced by parity. Controlled experiments can facilitate the monitoring of temporal trends in a trait or suite of traits, offering the potential to identify unfavorable trends early (Berry et al., 2014). It can also facilitate insights into traits that are not easily measured at the commercial farm level.

On that basis, a research herd was established at Teagasc Moorepark in 2011 comprising high-EBI cows (referred to here as the elite group) and cows represen- tative of the national average EBI (referred to here as the NA group). The Next Generation Herd project is a sentinel resource to provide a futuristic view of the phenotypic performance of animals selected for extremely high overall genetic merit as indicated by the Irish total merit index and EBI and to discern the relationship between selection for extremely high EBI and profitability in pasture-based systems of milk production. This study provided the opportunity to precisely identify the drivers of improved production performance in animals selected using EBI. The objective here was to investigate the milk production performance of 2 distinct genetic groups $(\mathbf{G G})$ of $\mathrm{HF}$ (elite and NA) and the interaction of GG with feeding treatment $(\mathbf{F T})$ and parity.

\section{MATERIALS AND METHODS}

This study was conducted at the Dairygold Research Farm (Teagasc, Animal and Grassland Research and Innovation Centre, Moorepark, Fermoy, Co. Cork, Ireland; $\left.52^{\circ} 09^{\prime} \mathrm{N} 8^{\circ} 16^{\prime} \mathrm{W}\right)$. Two GG of HF cows, elite and NA, were evaluated across 4 yr (2013-2016). In each year, 90 elite and 45 NA cows were included in the study. Mean parity structure of the elite and NA cows in each year of the study is presented in Table 1. Both GG were balanced for parity and calving date each year. Mean calving date was February $15( \pm 16$ d) and February $18( \pm 18$ d) for elite and NA cows, respectively; hence, production differences would represent true production potential independent of fertility or longevity.

\section{Animals}

The Irish national database, which is managed by the Irish Cattle Breeding Federation (http://www.icbf .com), comprises details of all dairy and beef cattle born in Ireland. The national database was screened to identify HF females born in spring 2011 and ranked within the top $5 \%$ of the HF breed (elite group) for genetic merit (EBI). Females with an EBI within 1 standard deviation of the mean EBI of HF females born in spring 2011 and with a milk subindex:fertility subindex ratio similar to their birth cohort were also identified (NA group). All suitable animals were genotyped to verify parentage and increase the reliability of predicted EBI using the Illumina Bovine50 beadchip (Matukumalli et al., 2009). To avoid confounding between EBI and the effects of hybrid vigor, or the dominance of individual sire lines, all animals identified were a minimum of $93.75 \% \mathrm{HF}$, and the number of daughters per sire and maternal grandsire was minimized $(\leq 8)$ to ensure 
Table 1. The number of cows in parities 1 to 4 represented in each year of the study across 2 genetic groups of Holstein-Friesian cows $^{1}$

\begin{tabular}{|c|c|c|c|c|c|c|c|c|}
\hline \multirow[b]{2}{*}{ Year } & \multicolumn{2}{|c|}{ Parity 1} & \multicolumn{2}{|c|}{ Parity 2} & \multicolumn{2}{|c|}{ Parity 3} & \multicolumn{2}{|c|}{ Parity 4} \\
\hline & Elite & NA & Elite & NA & Elite & NA & Elite & NA \\
\hline 1 & 90 & 45 & - & - & - & - & - & - \\
\hline 2 & 30 & 15 & 60 & 30 & - & - & - & - \\
\hline 3 & 24 & 12 & 24 & 12 & 42 & 21 & - & - \\
\hline 4 & 24 & 12 & 18 & 9 & 18 & 9 & 30 & 15 \\
\hline
\end{tabular}

${ }^{1}$ Elite $=$ high Economic Breeding Index; NA = national average Economic Breeding Index.

maximum genetic diversity. Over the lifetime of the study, the 177 individual elite cows represented 66 sires and 91 maternal grandsires, whereas the $95 \mathrm{NA}$ cows represented 52 sires and 48 maternal grandsires. Mean EBI and PTA of elite and NA cows used in the experiment, excluding the influence of own and progeny performance (ICBF, 2018), are presented in Table 2. Replacements for the elite cows were predominantly generated from within the herd using nationally available sire germplasm. Replacements for the NA cows were predominantly sourced externally to ensure that their EBI was reflective of year of birth in the national population.

\section{$F T$}

Cows within each GG were randomly assigned each year postpartum, in mid March and mid April for the early- and late-calving cows, respectively, to 1 of 3 experimental FT. Randomization was performed on the basis of EBI, parity, calving date, pre-experimental yield of milk solids (mean of $2 \mathrm{wk}$ ), BW, and BCS. The FT were designed to explore the expression of genetic potential under nutritional treatments ranging from slightly limited to generous nutrient supply within the context of seasonal grazing systems. The study was conducted per the project authorization AE19132/ P023 of the Health Products and Regulatory Authority (Dublin, Ireland). The control (CTL) treatment, designed to allow each GG to express its potential within a predominantly grazed grass diet, was characterized by a target postgrazing compressed sward height of 4.5 to $5 \mathrm{~cm}$ and a planned concentrate allowance of $300 \mathrm{~kg} /$ cow per year, offered during periods of pasture deficit, primarily in spring (Holmes et al., 2002). A lower grass allowance (LGA) treatment, designed to reflect a restricted feed supply, was characterized by a target postgrazing compressed sward height of 3.5 to $4 \mathrm{~cm}$ throughout (consistently $1 \mathrm{~cm}$ lower than CTL) and a planned concentrate allowance of approximately $300 \mathrm{~kg} /$ cow per year (consistent with CTL). A highconcentrate (HC) treatment, designed to allow each GG to express its potential within a grazing FT with increased nutrient availability, was characterized by a target postgrazing compressed sward height of 4.5 to $5 \mathrm{~cm}$ and a planned concentrate supplementation of $1,100 \mathrm{~kg}$ of concentrate/cow per year. The difference in concentrate allocation between $\mathrm{HC}$ and both CTL and LGA was a differential of $4 \mathrm{~kg}$ of concentrate/d once FT were applied.

Table 2. The mean Economic Breeding Index (EBI), EBI subindices, and PTA for milk production traits of the 2 genetic groups of Holstein-Friesian cows studied ${ }^{1}$

\begin{tabular}{lcccc}
\hline Item & Elite & SD & NA & SD \\
\hline EBI & 154 & 34.2 & 47 & 30.9 \\
Subindex (€) & & & & 77.5 \\
Milk & 28 & 20.0 & 28 & 22.7 \\
Fertility & 103 & 28.9 & 24 & 8.6 \\
Calving & 31 & 8.0 & -13 & 8.0 \\
Beef & -21 & 7.6 & -1 & 8.9 \\
Maintenance & 12 & 8.5 & & 4.6 \\
Health & 0 & 4.6 & 0.6 & 127.4 \\
PTA & -52.0 & 132.6 & 3.4 & 4.15 \\
Milk (kg) & 6.9 & 5.08 & 0.5 & 3.42 \\
Fat (kg) & 2.5 & 3.73 & 0.07 & 0.094 \\
Protein (kg) & 0.17 & 0.110 & 0.05 & 0.045 \\
Fat (\%) & 0.13 & 0.054 & & \\
Protein (\%) & & & \\
\hline
\end{tabular}

${ }^{1}$ Elite $=$ high EBI; NA = national average EBI. 


\section{Feed Supply and Grazing Management}

All animals were managed in a rotational grazing system. The experimental area was a permanent grassland site containing greater than $90 \%$ perennial ryegrass (Lolium perenne). Thirty elite cows and 15 NA cows were randomly assigned to each of the $3 \mathrm{FT}$ annually, and once allocated to treatments cows were grazed as 6 individual management groups within 6 discrete farmlets. Each elite farmlet consisted of 17 paddocks (on average $0.62 \mathrm{ha}$ ) per treatment. Each NA farmlet consisted of 17 paddocks (on average 0.31 ha) per treatment. The elite and NA cows within each FT grazed in adjacent paddocks. Each FT had an overall stocking rate of 2.75 livestock units/ha and a mineral $\mathrm{N}$ fertilizer input of $250 \mathrm{~kg}$ of N/ha (from early January to mid September). Cows grazed to a common target postgrazing compressed sward height of $3.5 \mathrm{~cm}$ during the postcalving pre-experimental period and were offered concentrate at a flat rate of $4 \mathrm{~kg}$ of $\mathrm{DM} /$ cow per day. All concentrate was offered in individual stalls in the milking parlor in 2 equal feeds each day.

Once treatments were implemented, paddock residency time was determined by the achievement of the predefined target postgrazing residual sward heights for each FT. All groups grazed similar pregrazing herbage masses ( $>4 \mathrm{~cm}$; Table 3$)$. Grazing management was achieved by recording the availability of grass on each paddock weekly within the PastureBase Ireland grassland decision support system (Hanrahan et al., 2017). Pasture was managed per the recommendations of O'Donovan (2000). The CTL and LGA treatments were offered a pasture-only diet from the date on which FT were implemented. Thereafter, concentrate was introduced for short periods to alleviate grass supply deficits only, with the differential of $4 \mathrm{~kg}$ in concentrate allocation between the $\mathrm{HC}$ treatment and both the CTL and LGA treatments maintained throughout. The cows remained on FT until housing in mid November each year and were housed thereafter full time until recalving. All animals were dried off by mid December. During the winter nonlactating period, animals were housed in a conventional indoor cubicle housing system. First-lactation animals were given a 10-wk dry period and $8 \mathrm{wk}$ in subsequent lactations. All animals were offered grass silage ad libitum during winter plus dry cow minerals at a rate of $100 \mathrm{~g} / \mathrm{d}$. The ingredient composition of the concentrate feed was similar in each year of the study and comprised barley $(250 \mathrm{~g} / \mathrm{kg})$, corn gluten $(260 \mathrm{~g} / \mathrm{kg})$, beet pulp $(350 \mathrm{~g} / \mathrm{kg})$, soybean meal $(110 \mathrm{~g} / \mathrm{kg})$, and minerals plus vitamins $(30 \mathrm{~g} / \mathrm{kg})$.

\section{Sward Measurements and Chemical Analysis}

Pre- and postgrazing compressed sward heights were determined for each paddock before and after grazing by taking 30 sward height measurements across the diagonal of the paddock using a rising plate meter

Table 3. Effect of genetic group (GG) of Holstein-Friesian cows, ${ }^{1}$ feeding treatment $(\mathrm{FT}),{ }^{2}$ and season ${ }^{3}$ on pregrazing herbage mass, pre- and postgrazing sward height, and pasture allowance during the experiment

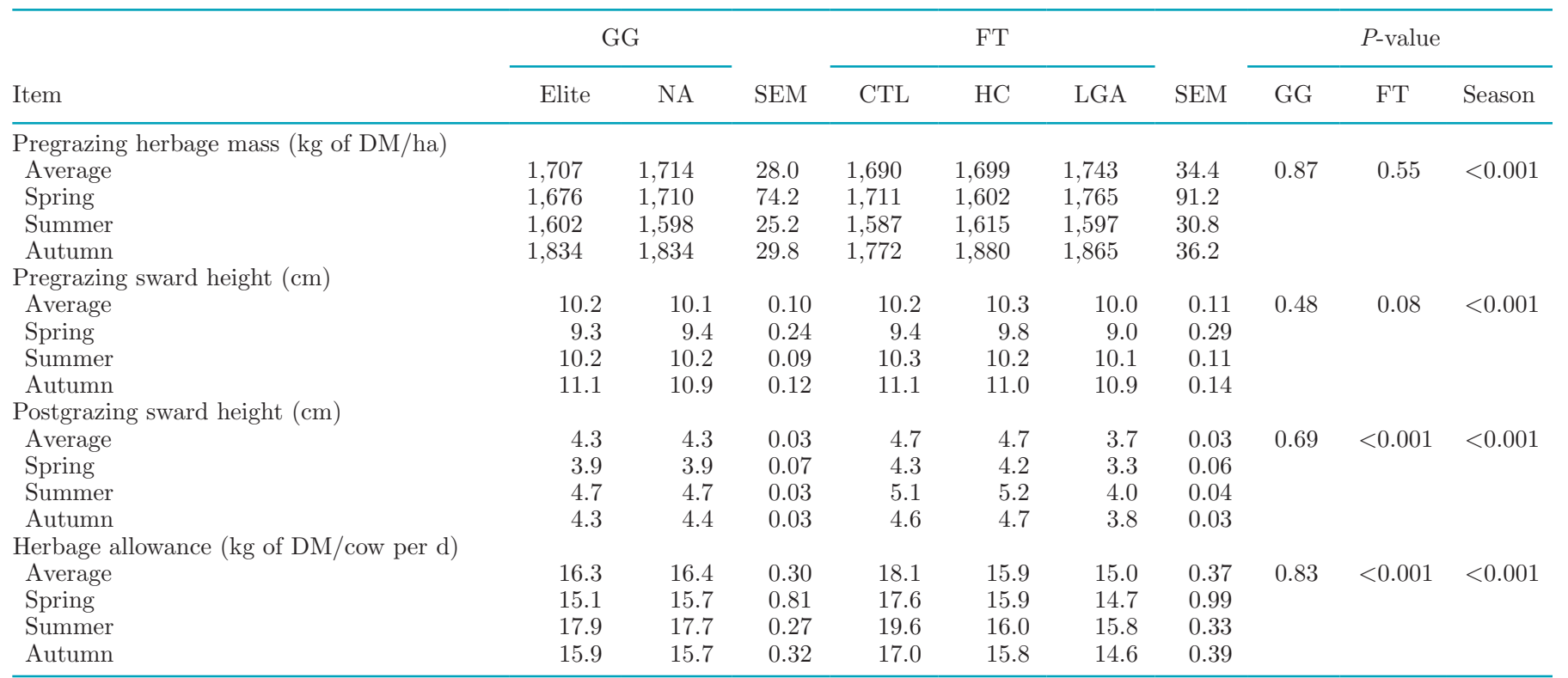

${ }^{1}$ Elite $=$ high Economic Breeding Index; NA = national average Economic Breeding Index.

${ }^{2} \mathrm{CTL}=$ high grass allowance; $\mathrm{HC}=$ high concentrate; LGA $=$ low grass allowance.

${ }^{3}$ Spring $=$ turnout to March 31; summer = April 1 to July 31; autumn = August 1 to housing. 
(Jenquip, Feilding, New Zealand). Pregrazing herbage mass ( $>4$-cm horizon) was determined weekly on a representative selection of paddocks to be grazed by each FT based on 4 strips of grass (1.2 m wide, 5-7 m long) cut using a rotary mower (Etesia, UK Ltd., Warwick, UK). The herbage from each cut was collected and weighed, and a subsample $(\sim 100 \mathrm{~g})$ was dried overnight at $90^{\circ} \mathrm{C}$ for $\mathrm{DM}$ determination. A further $100-\mathrm{g}$ bulked subsample of the fresh herbage from each paddock was oven dried overnight for $12 \mathrm{~h}$ at $60^{\circ} \mathrm{C}$, milled through a 1-mm sieve, and stored for chemical analysis. Composite herbage samples were subsequently analyzed for DM, ash, ADF, NDF (Van Soest et al., 1991), CP (Leco FP-428; Leco Australia Pty Ltd., Baulkham Hills, New South Wales, Australia), and OM digestibility (Fibertec Systems, Foss, Ballymount, Dublin, Ireland; Morgan et al., 1989). Concentrate samples were collected weekly and analyzed using near-infrared reflectance spectroscopy (Foss-NIR System DK, Foss Electric, Hillerød, Denmark) for DM, ash, CP, NDF, and crude fiber. During the winter period, silage samples were collected monthly and analyzed for DM, pH, ash, CP, DM digestibility, ADF, and NDF.

\section{Animal Measurements}

Cows were milked twice daily at 0700 and $1530 \mathrm{~h}$ throughout lactation. Weekly milk production was established from daily recording (morning and evening) of individual cow milk yield (MY; kg) using electronic milk meters (Dairymaster, Causeway, Co. Kerry, Ireland). Milk fat, protein, and lactose concentrations were determined weekly from successive p.m. and a.m. milk samples using a Milkoscan FT6000 (Foss Electric).

\section{Statistical Analyses}

Sward Measurements. The effects of GG, FT, year, and season on pregrazing herbage mass, pregazing compressed sward height, postgrazing compressed sward height, daily herbage allowance (DHA), and chemical composition of the herbage offered were analyzed using mixed models (PROC MIXED; SAS Institute Inc., 2017). The model comprised the fixed effects of GG, FT, and year, with season (spring: turnout to March 31; summer: April 1 to July 31; and autumn: August 1 to housing) included as a repeated effect. Paddock was included as the random effect. A compound symmetry covariance structure provided the best fit to the data.

Milk Production and Production Profiles. A total of 530 lactation records (355 elite, $175 \mathrm{NA}$ ) from 177 elite and 95 NA spring-calving HF dairy cows were represented in the data set. The fixed effects of
GG, FT, year, and parity and all 2- and 3-way interactions involving GG and FT on total lactation MY, yield of milk solids ( $\mathrm{kg}$ of fat plus protein), yield of solids-corrected milk (Tyrrell and Reid, 1965), and milk fat, protein, and lactose content were analyzed using PROC MIXED of SAS (SAS Institute Inc., 2017). Cow nested within GG was treated as the random effect, and the model was adjusted for calving day of year. A first-order autoregressive within-cow covariance structure was fitted. Interactions that were nonsignificant $(P>0.05)$ were eliminated from the model, with the final model consisting of all main effects. The effect of GG on response to reduced DHA was tested both over the full study and during specific lactation periods by comparing the differential in performance of each GG in the CTL treatment with the performance in the LGA treatment. Similarly, the overall and stage of lactation-specific responses to additional concentrate supplementation were tested to compare the differential in performance of each GG in the CTL and HC treatments.

The relationship between phenotypic milk production performance and genetic potential was investigated by regressing the phenotypic performance of milk, fat, and protein yield and milk fat and protein composition against their respective PTA using PROC MIXED of SAS. All models included fixed effects of FT, year, parity, and the interaction involving the respective PTA and FT.

Profiles of daily MY, milk solids, and milk fat, protein, and lactose content for each week of lactation were generated for the elite and NA groups within each FT and for each parity group within the elite and NA groups using a refinement of the previous model. In this model, GG, FT, year, and parity were treated as fixed effects and lactation week $\times$ year was treated as the repeated effect. The model was adjusted for calving day of year and the interval from calving to conception. The 2-way interactions between GG and FT and 3-way interactions involving GG, FT, and lactation week and GG, parity, and lactation week on daily yields of milk, milk solids, milk fat, protein, and lactose content were investigated, and all interactions were retained in the model. A compound symmetry covariance structure provided the best fit to the data. Peak yield of MY and milk solids was defined as the highest occurring daily yield by lactation week. Differences in the weekly decline in MY and milk solids yield from peak to wk 42 of lactation (before the commencement of drying off cows), expressed as a percentage of peak yield, and mean differences in the decline in MY and milk solids over 3 periods of lactation (wk 10-20, 20-30, and 30-42 of lactation) were also investigated. 


\section{RESULTS}

\section{Pasture Offered During Lactation}

The mean pregrazing herbage mass and pre- and postgrazing sward surface heights of the herbage offered throughout the study are presented in Table 3. Pregrazing sward heights and pregrazing yields were similar among FT, whereas differences in postgrazing compressed sward heights and concentrate input are in line with FT targets. Concentrate supplementation per cow was 318,313 , and $1,116 \mathrm{~kg}$ on average over the 4 yr for the CTL, LGA, and HC treatments, respectively. Residency time was longer for the LGA and HC treatments compared with the CTL treatment to achieve a lower residual in the case of LGA and due to the inclusion of additional concentrate in the $\mathrm{HC}$ diet. Paddock residency times for the CTL, LGA, and HC treatments on average were longer during the spring $(2.2,2.7$, and $2.5 \mathrm{~d}$, respectively) and autumn $(2.2,2.5$, and $2.5 \mathrm{~d}$, respectively), when growth rates were low, compared with summer months $(1.7,2.1$, and $1.9 \mathrm{~d}$, respectively), when paddock residency times were shorter due to lower pregrazing herbage yields and because increased growth rates required shorter rotation lengths to maximize sward quality and utilization, with surplus grass removed as silage. Rotation length was 52 and $45 \mathrm{~d}$, respectively, in spring (first rotation) and autumn (final rotation) compared with $21 \mathrm{~d}$ in summer months. The quality of herbage offered during spring, summer, and autumn is presented in Table 4. Herbage quality was superior during the spring and summer, with increased OM digestibility and lower NDF. Herbage ADF was similar in spring and summer and lower in autumn. Herbage CP content was greater in spring compared with the rest of the year. Means (standard deviations in parentheses) for DM, CP, NDF, crude fiber, and ash of the concentrate offered were 915.8 (8.0), 186.1 (21.3), 363.2 (44.1), 138.7 (13.1) and 54.5 (3.0) g/kg during spring, 914.0 (7.9), 164.8 (2.8), 361.8 (127.1), 129.3 (7.1), and 50.8 (5.6) g/kg during summer, and 914.1 (8.0), 170.2 (16.8), 380.1 (53.4), 144.0 (23.9), and 49.5 (4.8) $\mathrm{g} / \mathrm{kg}$ during autumn, respectively. No seasonal differences were observed in concentrate quality. Grass silage offered during the nonlactating period consisted of DM $246.1 \mathrm{~g} / \mathrm{kg}$ (3.95), $\mathrm{pH} 4.0$ (0.15), ash $76.0 \mathrm{~g} / \mathrm{kg}$ (0.75), CP $142.4 \mathrm{~g} / \mathrm{kg}(1.13), \mathrm{DM}$ digestibility $752.0 \mathrm{~g} /$ $\mathrm{kg}(2.54)$, and NDF $463.3 \mathrm{~g} / \mathrm{kg}(2.31)$.

\section{Effect of GG and FT on Total Lactation Performance}

No significant interaction between GG and FT was observed for any of the milk production variables investigated, nor was there any interaction between GG and parity; therefore, only the main effects of GG and FT on total lactation milk production performance are presented in Table 5 . The elite cows produced less milk per cow $(-205 \mathrm{~kg} ; P<0.01)$ compared with NA cows. Milk fat $(+2.8 \mathrm{~g} / \mathrm{kg})$ and protein $(+1.8 \mathrm{~g} / \mathrm{kg})$ contents were higher $(P<0.001)$ for elite compared with NA cows. Fat yield was higher $(P<0.05)$ for elite $(+6 \mathrm{~kg})$ cows, whereas protein yield was numerically higher for elite $(+2 \mathrm{~kg})$ compared with NA cows. Higher milk solids in favor of elite cows $(+8 \mathrm{~kg})$ approached significance $(P$ $=0.09$ ), whereas both solids-corrected milk and lactose content did not differ between elite and NA cows.

Feeding treatment had a significant effect on all milk production variables. Cows in the $\mathrm{HC}$ treatment produced higher $(P<0.001)$ MY, milk solids, and solidscorrected milk $(6,279,497$, and $6,282 \mathrm{~kg}$, respectively) compared with cows in the CTL treatment $(5,559,444$, and $5,614 \mathrm{~kg}$, respectively), whereas cows on the LGA treatment produced lower yields $(P<0.001)$ than those on the CTL treatment $(5,308,424$, and $5,368 \mathrm{~kg}$, respectively). Milk protein and lactose content were greater $(P<0.001)$ in the HC treatment $(36.7$ and $47.4 \mathrm{~g} / \mathrm{kg}$, respectively) compared with the CTL treatment (36.3 and $47.2 \mathrm{~g} / \mathrm{kg}$, respectively). Milk protein content was lower $(P<0.001)$ in the LGA treatment $(35.9 \mathrm{~g} / \mathrm{kg})$ compared with the CTL treatment. Milk fat content was lower $(P<0.001)$ in the HC treatment $(42.6 \mathrm{~g} /$ $\mathrm{kg})$ compared with the CTL treatment $(43.6 \mathrm{~g} / \mathrm{kg})$ and higher $(P<0.001)$ in the LGA treatment $(44.0 \mathrm{~g} / \mathrm{kg})$ compared with the CTL treatment.

\section{Effect of GG and FT on Milk Production by Lactation Stage}

There was no significant interaction between GG and FT during any stage of the lactation; therefore, the mean MY, milk solids, DHA, and concentrate supplementation for each GG within FT during wk 10 to 20, 20 to 30 , and 30 to 42 of lactation are presented in Table 6. The mean effect of GG on MY response to additional concentrate supplementation (HC vs. CTL) did not differ $(P=0.24)$ between elite and NA cows (0.96 vs. $1.09 \mathrm{~kg} / \mathrm{kg}$ additional concentrate), nor did it differ significantly by stage of lactation $(P=0.27)$. The mean milk production response to increased concentrate supplementation during wk 10 to 20,20 to 30 , and 30 to 42 of lactation was $1.03,0.95$, and $0.89 \mathrm{~kg}$ of milk $/ \mathrm{kg}$ of concentrate for elite cows and 1.24, 1.09, and $0.87 \mathrm{~kg}$ of milk $/ \mathrm{kg}$ of additional concentrate for NA cows, respectively. The mean effect of GG on milk solids response to increased concentrate supplementation did not differ $(P=0.70)$ between elite and NA cows (0.068 and $0.067 \mathrm{~kg}$, respectively), nor did it differ significantly during any stage of lactation $(P=0.76)$. 
Table 4. Seasonal ${ }^{1}$ variation in the chemical composition $(\mathrm{g} / \mathrm{kg})$ of pasture offered during the experiment

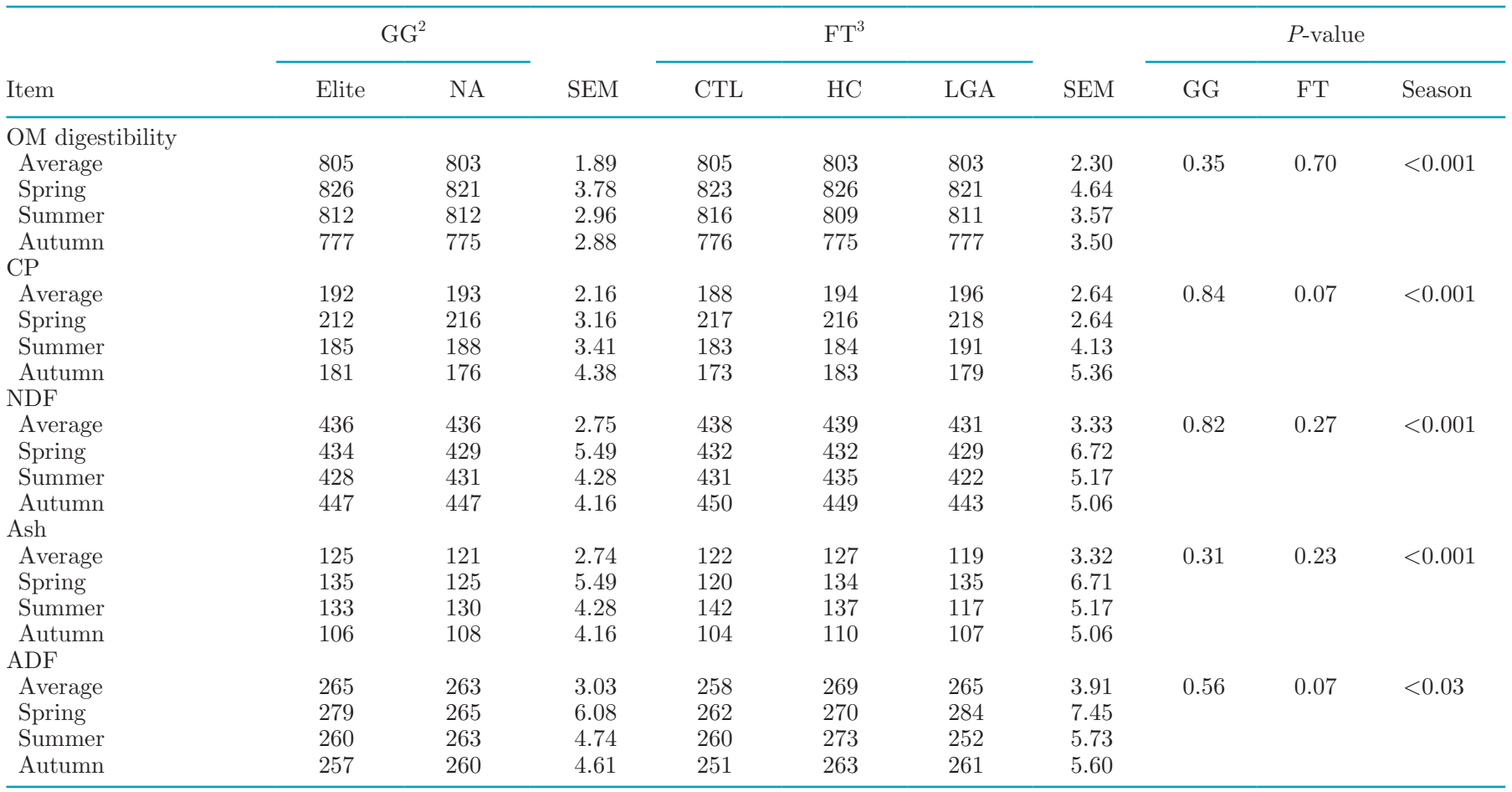

${ }^{1}$ Spring $=$ turnout to March 31; summer = April 1 to July 31; autumn = August 1 to housing.

${ }^{2}$ Genetic group (GG): elite = high Economic Breeding Index; NA = national average Economic Breeding Index.

${ }^{3}$ Feeding treatment $(\mathrm{FT}): \mathrm{CTL}=$ high grass allowance; $\mathrm{HC}=$ high concentrate; LGA $=$ low grass allowance.

Mean milk solids response to increased concentrate supplementation during wk 10 to 20,20 to 30 , and 30 to 42 of lactation, therefore, was $0.069,0.069$, and 0.064 $\mathrm{kg}$ of milk solids $/ \mathrm{kg}$ of concentrate.

The mean MY response to reduced herbage allowance did not differ between GG $(P=0.35)$, nor did it differ during any stage of lactation $(P=0.26)$. Mean responses to reduced herbage allowance during wk 10 to 20,20 to 30 , and 30 to 42 of lactation were -0.21 ,
-0.36 , and $-0.34 \mathrm{~kg}$ of milk $/ \mathrm{kg}$ decrease in DHA for elite cows and $-0.22,-0.64$, and $-0.43 \mathrm{~kg}$ of milk/ $\mathrm{kg}$ decrease in DHA for NA cows. Similarly, the mean milk solids response to reduced herbage allowance did not differ between GG $(P=0.30)$, nor did it differ across stage of lactation $(P=0.35)$. Mean milk solids responses to reduced herbage allowance during wk 10 to 20,20 to 30 , and 30 to 42 of lactation were -0.01 , -0.02 , and $-0.02 \mathrm{~kg}$ of milk solids $/ \mathrm{kg}$ increase in DHA

Table 5. Effect of genetic group (GG) of Holstein-Friesian cows $^{1}$ and feeding treatment $(\mathrm{FT})^{2}$ on milk production

\begin{tabular}{|c|c|c|c|c|c|c|c|c|c|c|}
\hline \multirow[b]{2}{*}{ Item } & \multicolumn{2}{|c|}{ GG } & \multirow[b]{2}{*}{ SEM } & \multicolumn{3}{|c|}{$\mathrm{FT}$} & \multirow[b]{2}{*}{ SEM } & \multicolumn{3}{|c|}{$P$-value } \\
\hline & Elite & NA & & CTL & $\mathrm{HC}$ & LGA & & GG & $\mathrm{FT}$ & Parity \\
\hline Milk yield (kg) & 5,613 & 5,818 & 56.7 & $5,559^{\mathrm{a}}$ & $6,279^{\mathrm{b}}$ & $5,308^{\mathrm{c}}$ & 54.9 & 0.004 & $<0.001$ & $<0.001$ \\
\hline \multicolumn{11}{|l|}{ Milk composition } \\
\hline Fat $(\mathrm{g} / \mathrm{kg})$ & 44.8 & 42.0 & 0.39 & $43.6^{\mathrm{a}}$ & $42.6^{\mathrm{b}}$ & $44.0^{\mathrm{c}}$ & 0.28 & $<0.001$ & $<0.001$ & 0.06 \\
\hline Protein (g/kg) & 37.2 & 35.4 & 0.16 & $36.3^{\mathrm{a}}$ & $36.7^{\mathrm{b}}$ & $35.9^{c}$ & 0.14 & $<0.001$ & $<0.001$ & $<0.001$ \\
\hline Lactose (g/kg) & 47.2 & 47.3 & 0.09 & $47.2^{\mathrm{a}}$ & $47.4^{\mathrm{b}}$ & $47.1^{\mathrm{a}}$ & 0.08 & 0.3 & $<0.001$ & $<0.001$ \\
\hline $\mathrm{MSD}^{3}$ yield (kg) & 459 & 451 & 3.8 & $444^{\mathrm{a}}$ & $497^{\mathrm{b}}$ & $424^{\mathrm{c}}$ & 3.8 & 0.09 & $<0.001$ & $<0.001$ \\
\hline $\mathrm{SCM}^{4}$ yield (kg) & 5,770 & 5,739 & 47.8 & $5,614^{\mathrm{a}}$ & $6,282^{\mathrm{b}}$ & $5,368^{\mathrm{c}}$ & 47.8 & 0.6 & $<0.001$ & $<0.001$ \\
\hline
\end{tabular}

\footnotetext{
${ }^{\mathrm{a}-\mathrm{c}}$ Means within a row without a common superscript differ.

${ }^{1}$ Elite $=$ high Economic Breeding Index; NA = national average Economic Breeding Index.

${ }^{2} \mathrm{CTL}=$ high grass allowance; $\mathrm{HC}=$ high concentrate; LGA $=$ low grass allowance.

${ }^{3}$ Milk solids (fat + protein; $\mathrm{kg}$ ).

${ }^{4}$ Solids-corrected milk.
} 
MILK PRODUCTION OF COWS OF DIVERGENT ECONOMIC BREEDING INDEX

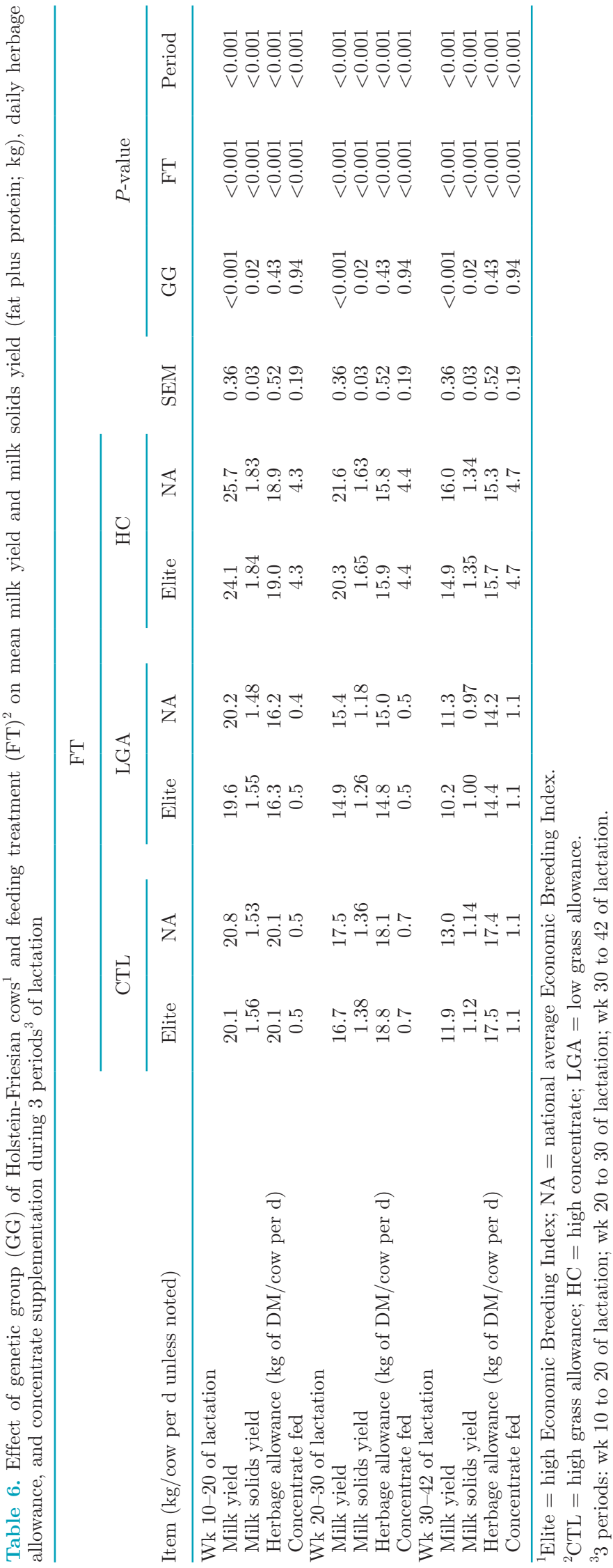

for elite cows and $-0.02,-0.05$, and $-0.03 \mathrm{~kg}$ of milk solids $/ \mathrm{kg}$ decrease in DHA for NA cows.

\section{Milk Production Profiles}

Profiles of daily MY and daily milk solids by week of lactation for the elite and NA cows within FT are presented in Figures 1 and 2, respectively. The profiles illustrate that the mean differences observed between elite and NA cows for MY and milk solids yield emerged from wk 8 and tended to be consistent between GG thereafter. Higher MY and milk solids production were consistently achieved from wk 8 of lactation with increasing plane of nutrition, increasing from LGA to CTL to HC treatments. Details pertaining to lactation profiles are displayed in Table 7. Peak MY occurred between wk 7 and 8 of lactation, similar for elite and NA cows. The weekly decline in MY from peak to wk 42 of lactation, expressed as a percentage of peak MY, was greater $(P<0.05)$ for elite cows $(1.8 \%$ of peak supply) compared with NA cows (1.6\% of peak supply). The decline in MY between wk 10 and 20 of lactation was greater $(P<0.05)$ for elite cows $(0.44 \mathrm{~kg} /$ wk $)$ compared with NA cows $(0.39 \mathrm{~kg} / \mathrm{wk})$, with no difference in the decline in weekly MY observed between GG from wk 20 to 30 of lactation or from wk 30 to 42 of lactation.

There was a significant effect of FT on the occurrence of peak MY. Peak MY occurred at wk 7 of lactation within both the CTL and LGA FT, whereas peak MY occurred at wk 9 of lactation within the HC FT. There was also a significant effect of FT $(P<0.001)$ on the decline in MY from wk 10 to wk 20 of lactation and from wk 30 to wk 42 of lactation $(P<0.001)$. Cows on the LGA treatment experienced a greater weekly reduction in MY $(0.52 \mathrm{~kg})$ compared with those on the CTL treatment $(0.42 \mathrm{~kg})$ during wk 10 to 20 of lactation. Cows on the HC treatment experienced a greater weekly reduction in MY $(0.68 \mathrm{~kg})$ with) compared with those on the CTL treatment $(0.54 \mathrm{~kg})$ during wk 30 to 42 of lactation.

Peak milk solids occurred at wk 7 of lactation for both elite and NA GG. The decline in milk solids from peak to wk 42 of lactation, expressed as a percentage of peak milk solids yield, was greater $(P<0.05)$ with elite cows compared with NA cows (1.5 vs. $1.4 \%$, respectively). Although a numerically greater decline in milk solids yield from wk 10 to wk 20, wk 20 to wk 30, and wk 30 to wk 42 of lactation was observed with elite cows compared with NA cows, the declines in each period did not differ significantly between GG. There was a significant effect of FT $(P<0.001)$ on the decline in weekly milk solids yield from wk 10 to wk 20 of lactation. Cows on the LGA treatment experienced a greater weekly reduction in milk solids yield (0.034 


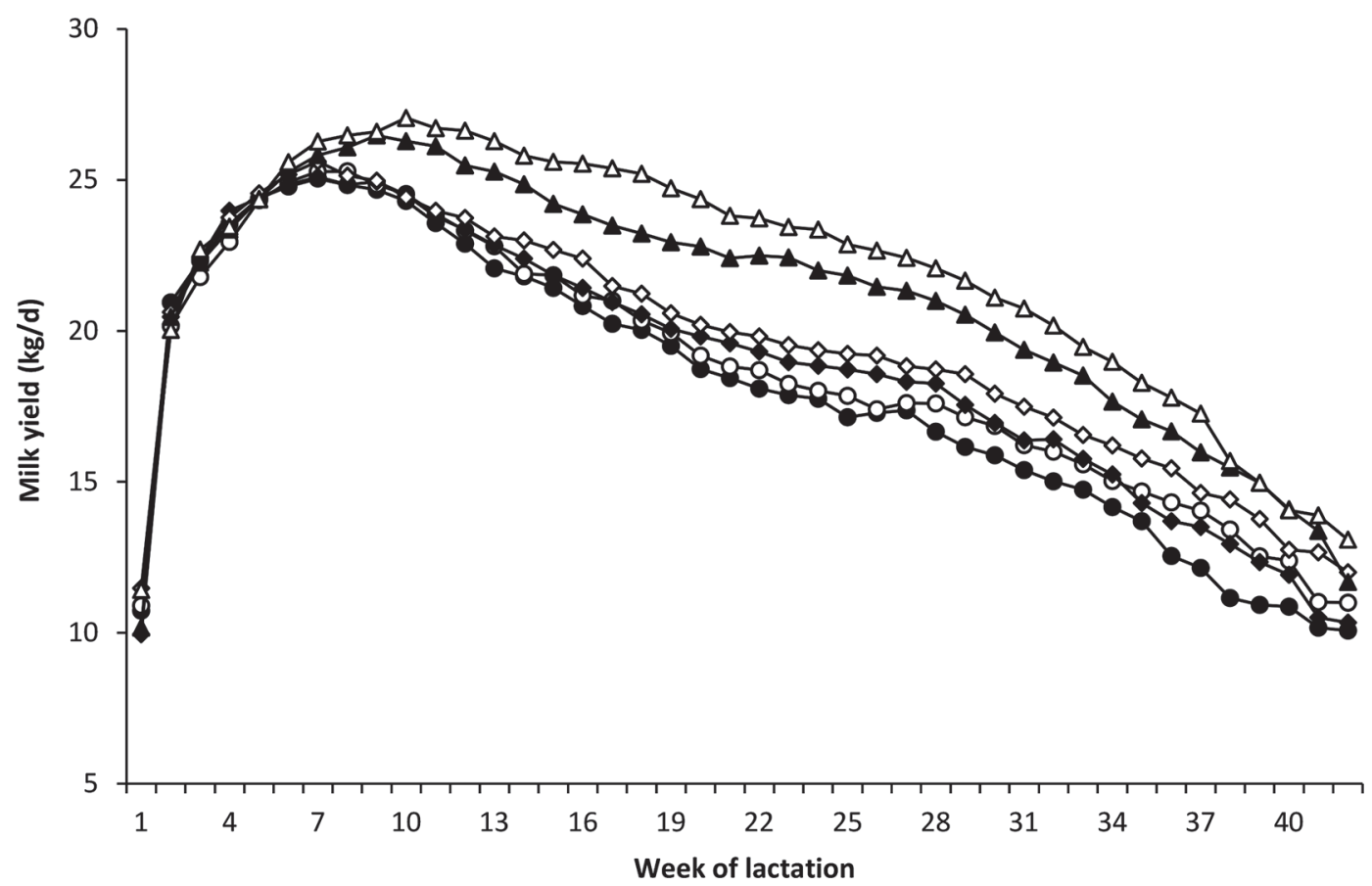

Figure 1. The effect of cow genetic group (elite = high Economic Breeding Index; NA = national average Economic Breeding Index) within feeding treatment $(\mathrm{CTL}=$ high grass allowance; $\mathrm{HC}=$ high concentrate; LGA $=$ low grass allowance) on daily milk yield for each week of lactation. $\boldsymbol{\Delta}=$ elite, HC; $\Delta=\mathrm{NA}, \mathrm{HC} ; \bullet=$ elite, CTL; $\diamond=\mathrm{NA}, \mathrm{CTL} ; \bullet=$ elite, LGA; $\bigcirc=\mathrm{NA}, \mathrm{LGA}$.

$\mathrm{kg}$ of milk solids) from wk 10 to wk 20 of lactation compared with cows on the CTL treatment $(0.028 \mathrm{~kg}$ of milk solids). Cows on the HC treatment experienced a lower weekly reduction in milk solids yield $(0.019 \mathrm{~kg}$ of milk solids) compared with cows on the CTL treatment from wk 10 to wk 20 of lactation. The decline in milk solids yield from wk 20 to wk 30 and from wk 30 to wk 42 of lactation did not differ significantly across FT.

Daily milk fat, protein, and lactose concentration profiles for the elite and NA cows within each FT by week of lactation are presented in Figures 3, 4, and 5, respectively. The profiles clearly reflect the total lactation outcomes for GG and FT and show consistent trends over lactation. Fat concentration (Figure 3) was greater throughout lactation for the elite cows compared with the NA cows across all $3 \mathrm{FT}$. A decline in fat and protein concentration was observed in both GG postpartum. The lowest fat concentration occurred at wk 11 in both GG across all 3 FT. Protein concentration (Figure 4) was greater throughout lactation in the elite cows compared with the NA cows across all 3 FT. The lowest protein concentration occurred at wk 6 in both GG across all 3 FT. Lower fat and protein concentrations at the turning point of the lactation profile were observed in NA animals compared with elite animals. A greater divergence in the lactation profiles for fat and protein concentration is evident between elite and NA cows from the turning point of the lactation profile to the end of lactation in all 3 FT. The lactation profile for lactose concentration showed a similar trend for elite and NA cows within each of the $3 \mathrm{FT}$.

\section{Regression of Phenotypic Performance on PTA}

Regression coefficients for yields of milk, fat, protein, fat concentration, and protein concentration on their respective PTA values across all cows were all significantly different from zero (Table 8). The outcomes indicate a positive relationship between PTA value and phenotypic performance. Each increment in PTA value for MY represented a $1.66-\mathrm{kg}$ increase in milk volume across FT. A significant interaction between PTA and FT was observed for MY $(P<0.01)$, fat yield $(P<$ $0.01)$, and protein yield $(P<0.01)$. Each incremental increase in PTA for milk represented an increase of $1.20,1.56$, and $2.45 \mathrm{~kg}$ in phenotypic MY in the CTL, LGA, and HC treatments, respectively. Each incremental increase in PTA for fat yield and protein yield represented an increase of $0.8 \mathrm{~kg}$ of fat and $0.4 \mathrm{~kg}$ of protein in the CTL treatment, $1.46 \mathrm{~kg}$ of fat and 1.08 $\mathrm{kg}$ of protein in the LGA treatment, and $2.10 \mathrm{~kg}$ of fat and $2.0 \mathrm{~kg}$ of protein in the $\mathrm{HC}$ treatment. There was no significant interaction between PTA and FT for fat concentration or protein concentration. Each incremen- 
tal increase in PTA for fat concentration and protein concentration represented an increase of $2.33 \mathrm{~g} / \mathrm{kg}$ of fat and $1.97 \mathrm{~g} / \mathrm{kg}$ of protein in the CTL treatment, $2.51 \mathrm{~g} / \mathrm{kg}$ of fat and $2.34 \mathrm{~g} / \mathrm{kg}$ of protein in the LGA treatment, and $2.39 \mathrm{~g} / \mathrm{kg}$ of fat and $2.20 \mathrm{~g} / \mathrm{kg}$ of protein in the $\mathrm{HC}$ treatment.

\section{Effect of Parity}

Fourth-parity cows produced the greatest MY $(6,455$ $\mathrm{kg})$ and milk solids $(518 \mathrm{~kg})$. First-, second-, and thirdparity cows produced $72 \%(4,662 \mathrm{~kg}), 86 \%(5,532 \mathrm{~kg})$, and $96 \%(6,212 \mathrm{~kg})$ of the MY and $71 \%(369 \mathrm{~kg}), 85 \%$ $(440 \mathrm{~kg})$, and $96 \%(495 \mathrm{~kg})$ of the milk solids yield of fourth-parity cows. Profiles of daily MY and milk solids yield by week of lactation for each parity number within GG (Figures 6 and 7) further demonstrate the consistency of production with increasing parity across GG.

\section{DISCUSSION}

\section{Genetic Influence of EBI on Production}

Selection of cows for dairy production systems in Ireland has undergone considerable change. Historically, breed substitution formed the basis for genetic upgrading of the Irish dairy herd (Evans et al., 2006). However, over the past $20 \mathrm{yr}$ the Irish dairy industry has progressed from a situation of almost total dependence on imported Holstein genetics to the establishment of the EBI (Veerkamp et al., 2002) and the implementation of a comprehensive national breeding program (Kearney et al., 2018), with the vast majority of replacement females generated from genomically selected young bulls of indigenous origin (ICBF, 2016a). The uptake of the EBI as a genetic selection tool has been high, as evidenced by the high level of usage of genomically selected bulls and positive national genetic gain trends (ICBF, 2016b).

Several studies have compared the milk production performance of strains of HF selected on different breeding objectives (Buckley et al., 2000a; Horan et al., 2005b; Roche et al., 2006). Ramsbottom et al. (2012) investigated the performance of dairy cows on commercial Irish dairy farms. Although these studies have provided direction in terms of the philosophy of genetic selection of dairy cattle in Ireland, none has served as a direct validation of the efficacy of selection using EBI. The present study is unique, providing a future view of how animals selected on EBI can be expected to perform on Irish dairy farms and a validation of the breeding objective.

Following extensive industry consultation (Veerkamp et al., 2000), initial economic values on milk and its components within the EBI were derived to reflect the industrial value of milk components (Veerkamp et al., 2002). The requirement for milk with high solids content is unique to Ireland, and to New Zealand, where milk payment is directly dependent on milk composition rather than volume (Breen et al., 2007). This is a reflection of the export-orientated product mix (Geary

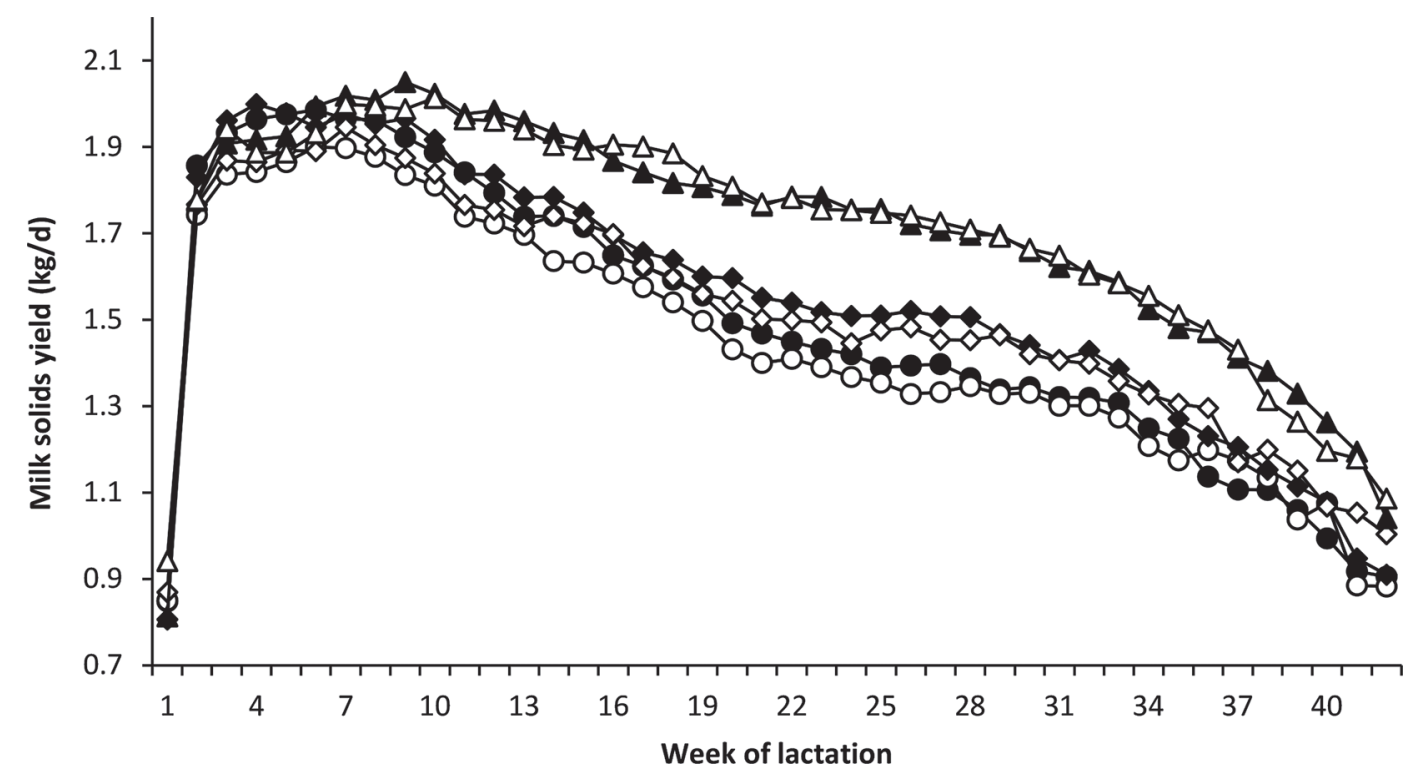

Figure 2. The effect of cow genetic group (elite = high Economic Breeding Index; NA = national average Economic Breeding Index) within feeding treatment $(\mathrm{CTL}=$ high grass allowance; $\mathrm{HC}=$ high concentrate; LGA $=$ low grass allowance) on daily milk solids yield for each week of lactation. $\boldsymbol{\Delta}=$ elite, HC; $\Delta=\mathrm{NA}, \mathrm{HC} ; \bullet=$ elite, CTL; $\diamond=\mathrm{NA}, \mathrm{CTL} ; \bullet=$ elite, LGA; $\mathrm{O}=\mathrm{NA}, \mathrm{LGA}$. 


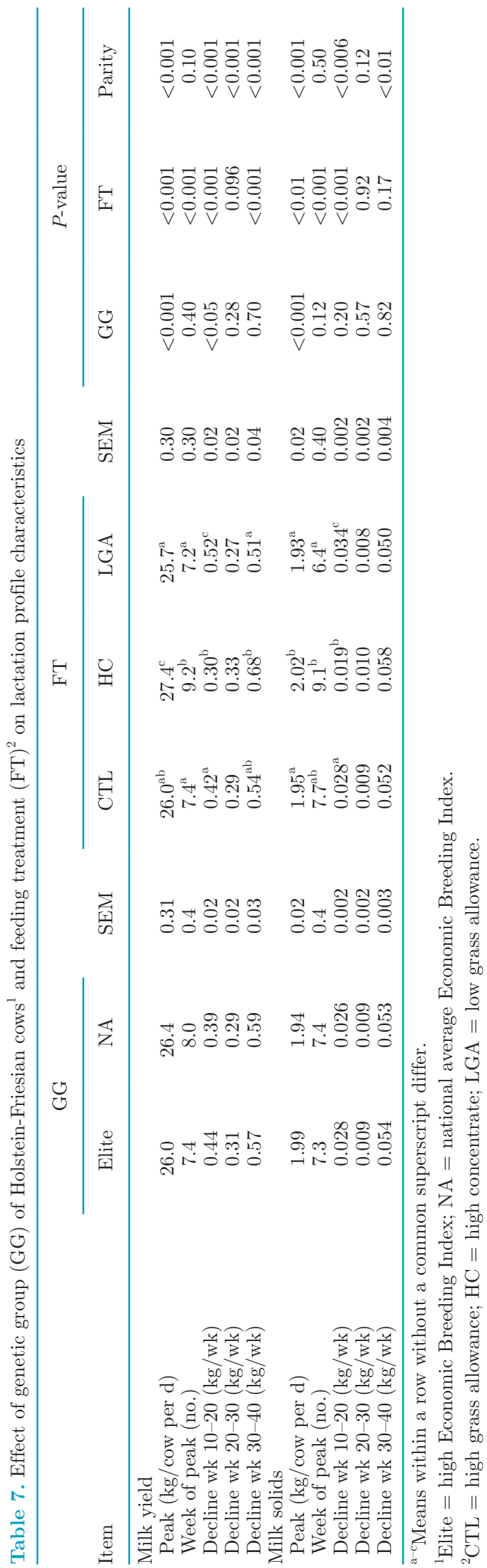

et al., 2010) relative to the global mainstream of internal fluid milk markets. Milk processors in Ireland currently pay for milk purchased on a multiple component "A + B - C system" pricing system basis, representing the values per kilogram of fat (A) and protein (B) and the carrier and processing costs per kilogram (C; commonly referred to as the "volume adjustment"; Geary et al., 2010). Dairy cows with higher yields of fat and protein typically have advantages in grazing systems that supply milk to solids-based markets (Washburn and Mullen, 2014). Current economic weightings on milk production traits within the EBI (ICBF, 2017) reflect the economic reward to both the farmer and the processor of increases in the quantities of kilograms of milk fat and milk protein supplied (Geary et al., 2010). Phenotypic trends in milk production of Irish dairy cows show consistent increases in yields of milk fat and protein and the concentration of milk fat and milk protein (ICBF, 2016b). The lower MY, superior milk solids production per cow, and increased milk composition throughout lactation of the elite cows compared with NA contemporaries in the current study are consistent with the national breeding objective, exemplifying agreement between selection criteria and producer goals (Delaby et al., 2018), and demonstrate that genetics suitable to pasture-based systems with HF can be identified. Furthermore, the differences observed in milk production performance between elite and NA cows represent true production potential differences, independent of the consequences of fertility performance. The results of this study concur with the findings of Ramsbottom et al. (2012), who observed that higher EBI was associated with reduced MY but with greater milk composition on commercial dairy farms, albeit using commercial animals of lower genetic merit than those in the present study. Sward characteristics and herbage quality offered in the present study were comparable with that reported in previous studies at this research center (Coleman et al., 2010; Coffey et al., 2018) and were consistent across the elite and NA GG and for all $3 \mathrm{FT}$. Indeed, the high level of pasture management in the present study was reflected in the absolute level of protein composition of the milk produced in all $3 \mathrm{FT}$.

\section{Effect of GG and FT on Milk Production}

Increasingly volatile milk prices coupled with rising land costs have resulted in an increased diversity of pasture-based production systems in temperate grazing regions such as Ireland and New Zealand (Roche et al., 2017). Variation does exist within seasonal pasture-based systems due to circumstance, such as constraints of land availability adjacent to the milk- 
ing parlor (Patton et al., 2016), and even individual producer preference. Increased stocking densities as reviewed by McCarthy et al. (2011) and the provision of additional feed as a supplement to pasture (Bargo et al., 2003; Kennedy et al., 2003; Coleman et al., 2010) are examples of strategies for facilitating increased milk solids production from limited land resources. In the context of the current breeding objective, knowledge of the ability of cows selected on EBI to cope with these feeding challenges but equally to respond when offered additional feed is essential to ensure the selection of appropriate animals. The lack of any significant interaction between GG and FT in the present study indicates the ability of cows selected on EBI to perform across contrasting feeding management levels. A greater divergence in both EBI and feeding level may result in an interaction between GG and FT; the breadth of the FT in the present study reflects the upper and lower limits of recommended best practice to maximize productivity in Irish milk production systems (O'Donovan et al., 2011).

Response to supplemental feed is a reflection of the level of nutrition of the animal at pasture and resulting substitution of pasture for concentrate. The lower the substitution rate, the greater the response to increased concentrate supplementation (Kellaway and Porta, 1993). Given the consistent high responses to additional herbage and concentrate supplementation observed in the current study, it can be concluded that the weightings on milk production within the EBI are sufficient to maintain high productivity levels in re- sponse to increased or restricted feed availability. Horan et al. (2005b) observed lower responses to concentrate supplementation with an HF strain of New Zealand origin compared with 2 North American strains. Although cows being capable of meeting energy requirements almost entirely from grazed pasture has been postulated by Buckley et al. (2005) and Delaby et al. (2018) as a key requirement for pasture-based systems, efficient conversion of available pasture to milk solids and efficient use of supplemental feeds are desirable for maintaining high levels of productivity and efficiency. Robust animals have the ability to overcome variability in the nutritional environment in terms of feed quality and quantity and make maximum use of the available nutritional resource (Friggens et al., 2017). The robustness of elite cows in the present study was demonstrated in their consistent superiority in milk solids and milk composition and numerically lower reduction in performance due to reduced herbage availability relative to NA cows.

\section{Lactation Persistency}

The lactation profiles for MY and milk solids of the elite and NA animals in the present study indicated consistent biological superiority of elite animals through the production of lower volumes of high-composition milk throughout lactation, with increasing milk fat and protein content as the lactation progressed. No antagonism was evident between selection for EBI and lactose content, which is important particularly in late

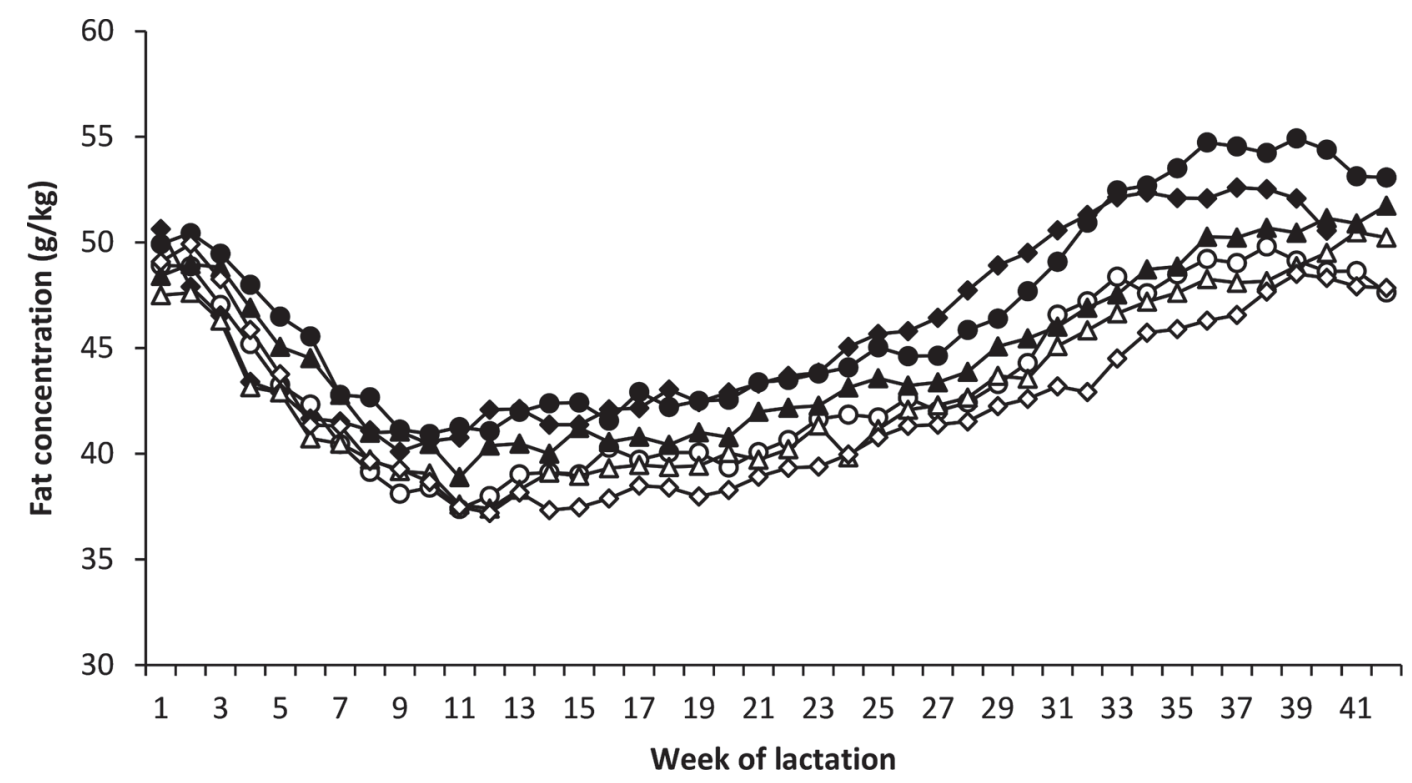

Figure 3. The effect of cow genetic group (elite = high Economic Breeding Index; NA = national average Economic Breeding Index) within feeding treatment $(\mathrm{CTL}=$ high grass allowance; $\mathrm{HC}=$ high concentrate; LGA $=$ low grass allowance) on daily fat concentration for each week of lactation. $\boldsymbol{\Delta}=$ elite, HC; $\Delta=\mathrm{NA}, \mathrm{HC} ; \bullet=$ elite, CTL; $\diamond=\mathrm{NA}, \mathrm{CTL} ; \bullet=$ elite, LGA; $\mathrm{O}=\mathrm{NA}, \mathrm{LGA}$. 


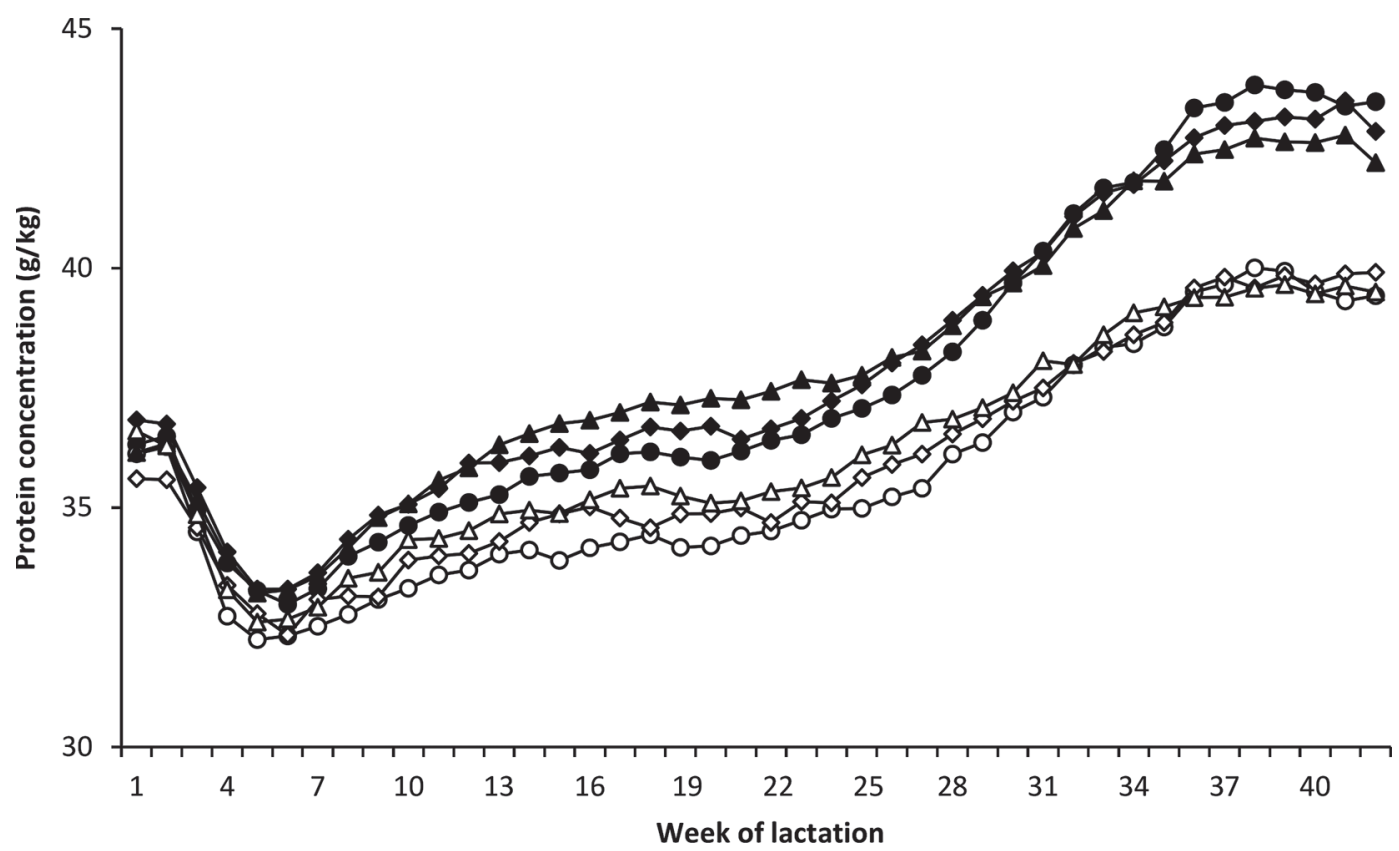

Figure 4. The effect of cow genetic group (elite = high Economic Breeding Index; NA = national average Economic Breeding Index) within feeding treatment $(\mathrm{CTL}=$ high grass allowance; $\mathrm{HC}=$ high concentrate; LGA $=$ low grass allowance) on daily protein concentration for each week of lactation. $\boldsymbol{\Delta}=$ elite, HC; $\Delta=\mathrm{NA}, \mathrm{HC} ; \bullet=$ elite, CTL; $\diamond=\mathrm{NA}$, CTL; $\bullet=$ elite, LGA; $\bigcirc=$ NA, LGA.

lactation in a seasonal calving environment because low lactose content negatively affects the processability of late-lactation milk (O'Brien et al., 1996).

Lactation persistency can be defined simply as the rate of decline in MY after peak yield and is consid- ered a trait of economic importance due to its effect on feed costs as well as health and fertility (Dekkers et al., 1996). The suggested trend for reduced persistency in the lactation profile of elite animals for both MY and milk solids in the present study was confirmed by

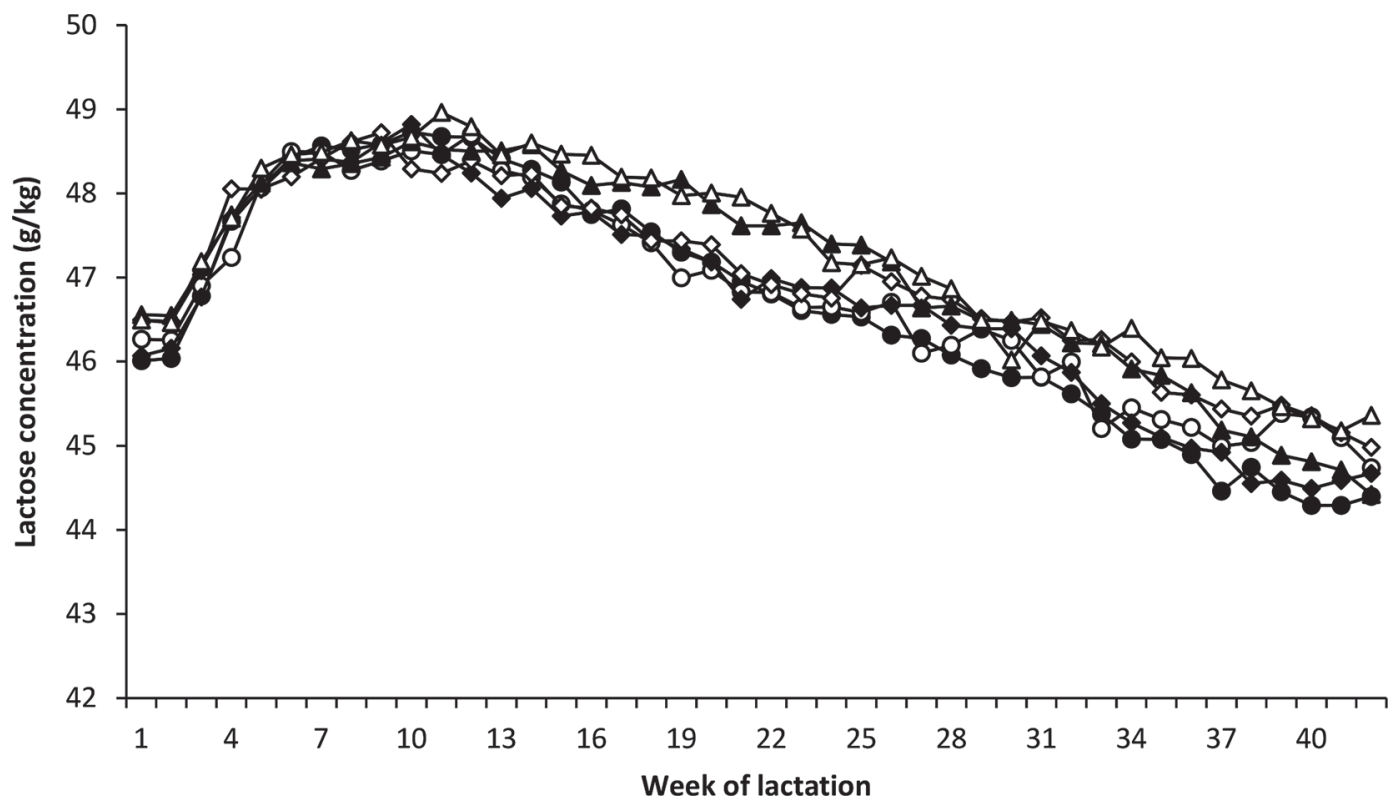

Figure 5. The effect of cow genetic group (elite = high Economic Breeding Index; NA = national average Economic Breeding Index) within feeding treatment $(\mathrm{CTL}=$ high grass allowance; $\mathrm{HC}=$ high concentrate; LGA $=$ low grass allowance) on daily lactose concentration for each week of lactation. $\boldsymbol{\Delta}=$ elite, HC; $\Delta=\mathrm{NA}, \mathrm{HC} ; \bullet=$ elite, CTL; $\diamond=\mathrm{NA}$, CTL; $\bullet=$ elite, LGA; $\bigcirc=$ NA, LGA 
O'Sullivan et al. (2018), who analyzed the shape of the lactation curve of the animals in the present study using the mathematical model developed by Wilmink (1987) and observed a significantly greater decline phase in the lactation curve for milk solids yield in elite animals. This is perhaps counterintuitive given the findings of Horan et al. (2005a), who observed greater persistency in an HF strain of New Zealand origin, a genotype also selected under grazing, although with a lower production potential. Previous research studies have highlighted the effect of pregnancy on milk production (Erb et al., 1952; Olori et al., 1997; Roche, 2003), with declining MY observed midway through lactation in pregnant cows. Adjustments were made in the present data for differences between elite and NA cows in their respective intervals from calving to conception; therefore, the effects of pregnancy on the lactation curve for milk production should be accounted for in the present study. Notwithstanding, the trends observed in elite cows raise the issue of lower persistency of lactation and underline the value of this study to contribute to the refinement of the EBI. The lower persistency is confined to the ability to maintain peak yield, and the magnitude of differences observed is small; nevertheless, this highlights the potential for further gains in productivity that could be achieved by improving lactation persistency among elite animals through more precise selection. The recent introduction of the test day model to Irish genetic evaluations (ICBF, 2018a), replacing the standard 305-d lactation curve method (Olori and Galesloot, 1999), may have the potential to better identify genetics within the HF population with the ability to transmit increased persistency of lactation, thus increasing the potential value of milk produced.

\section{Regression of Phenotypic Performance on PTA}

Although the relationship between selection on EBI and performance in specific production traits such as $\mathrm{MY}$ is of potential interest, due to the bimodal nature of the data (Figure 8) - a consequence of the $2 \mathrm{GG}$ being established on the basis of divergent EBI-the relationship between each unit increment in EBI and performance in each of the production traits is potentially invalid due to Simpson's paradox (Samuels, 1993), found to occur in the current data set. However, the associations between PTA and the performance in the respective milk production traits are valid due to the unimodal normal distribution of PTA values among experimental animals (Figure 9).

The milk production differential observed in the present study is broadly in line with expectation based on mean PTA differences but also by the regression of 
phenotypic performance on PTA. Regression analysis of the phenotypic performance of animals in the present study indicates that each increment in PTA value for $\mathrm{MY}$ is associated with a $1.66 \mathrm{-kg}$ increase in milk volume. Theoretically, each unit increase in PTA should result in a 2-unit increase in performance within that trait, with other conditions remaining the same (Simm, 1998). Considering that pasture quality in the current study is likely to be superior to that at average farm level, the MY response achieved is in line with that expected, particularly when the position of concentrate feeding levels within treatments in the present study is compared with concentrate feeding $(\sim 950 \mathrm{~kg})$ at the commercial farm level (Hennessy and Moran, 2016). The relationships observed between PTA and MY at contrasting feeding levels further demonstrate the greater expression of genetic potential at higher concentrate feeding levels reported previously (Kennedy et al., 2003). Both the lower than expected association between PTA and phenotypic performance and the differential between PTA and mean effects of production performance suggest potential overestimation of performance based on PTA in the present study, particularly for fat and protein yield. The absolute difference between elite and NA cows in PTA for fat and protein $(+4$ and +2 $\mathrm{kg}$, respectively) and phenotypic performance for fat and protein yield $(+6$ and $+2 \mathrm{~kg}$, respectively) suggests potential overestimation of performance based on PTA. The regression of milk fat and protein concentration on their respective PTA demonstrates the relationship between selection for increased milk composition and greater phenotypic performance in these traits, in line with expectation.

\section{Effect of Parity}

The absolute differences in production levels increasing from first parity to fourth parity in the present study were consistent across both GG within each of the respective FT and are in agreement with the differences reported previously among Irish dairy cattle (Hutchinson et al., 2013). Increases in production from first to second lactation in the present study are consistent with the findings of Heins and Hansen (2012) and Horan et al. (2005b), who reported consistent trends in the MY of strains of HF cows across parities, indicating that HF cows of divergent genetic merit and origin produce similarly as they mature. The observed milk production profiles for each parity number in the present study clearly demonstrate that MY and milk solids increases proportionately with increasing parity, with consistent increases across both GG.

\section{Future Considerations}

Although the results of the present study indicate that elite cows display compatibility with grazing systems and display production characteristics consistent with the breeding objective, 2 weaknesses of elite animals have been identified, requiring further attention. The superiority of elite animals arises from higher peak milk solids production and poorer subsequent

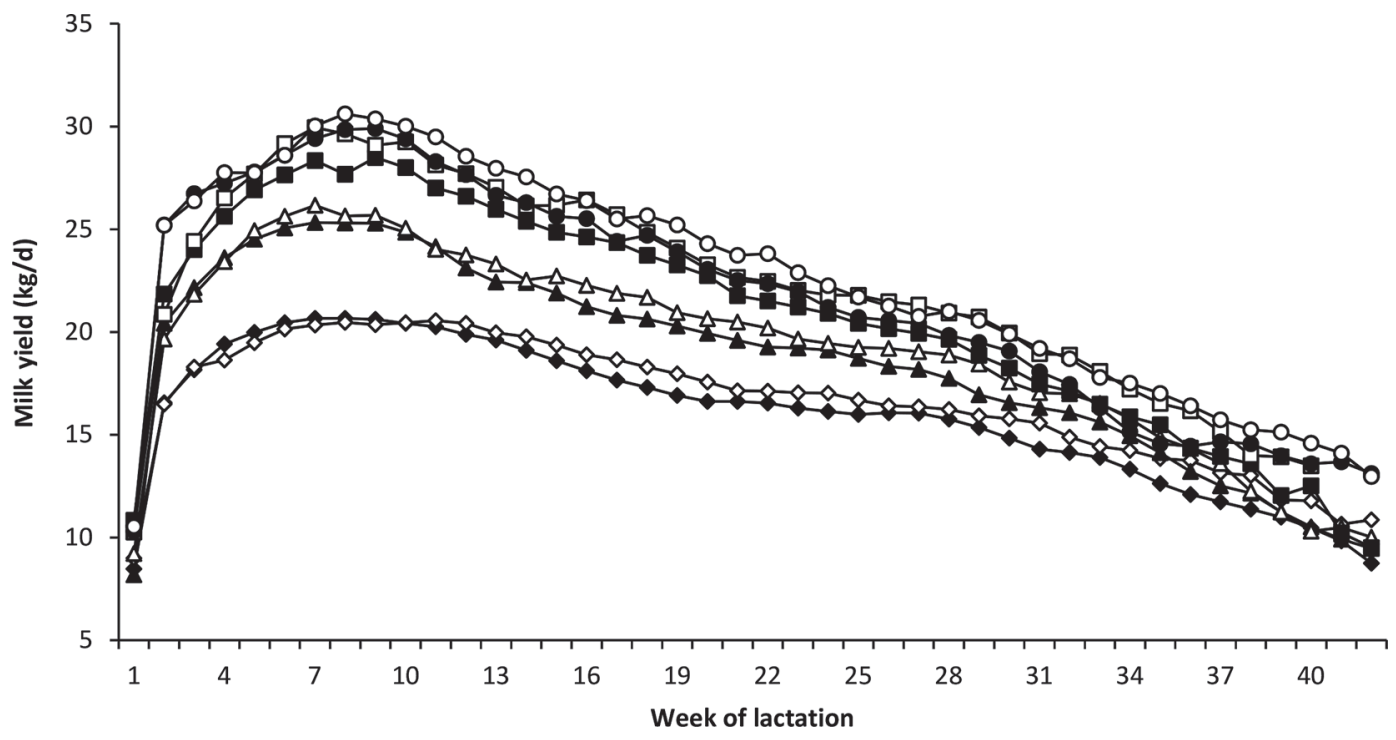

Figure 6. The effect of cow genetic group (elite = high Economic Breeding Index; NA = national average Economic Breeding Index) and parity number on daily milk yield for each week of lactation. $\bullet=$ elite, parity $4 ; \bigcirc=$ NA, parity $4 ; \boldsymbol{\square}=$ elite, parity $3 ; \square=$ NA, parity $3 ; \boldsymbol{\Lambda}=$ elite, parity $2 ; \Delta=\mathrm{NA}$, parity $2 ; \diamond=$ elite, parity $1 ; \diamond=\mathrm{NA}$, parity 1 . 


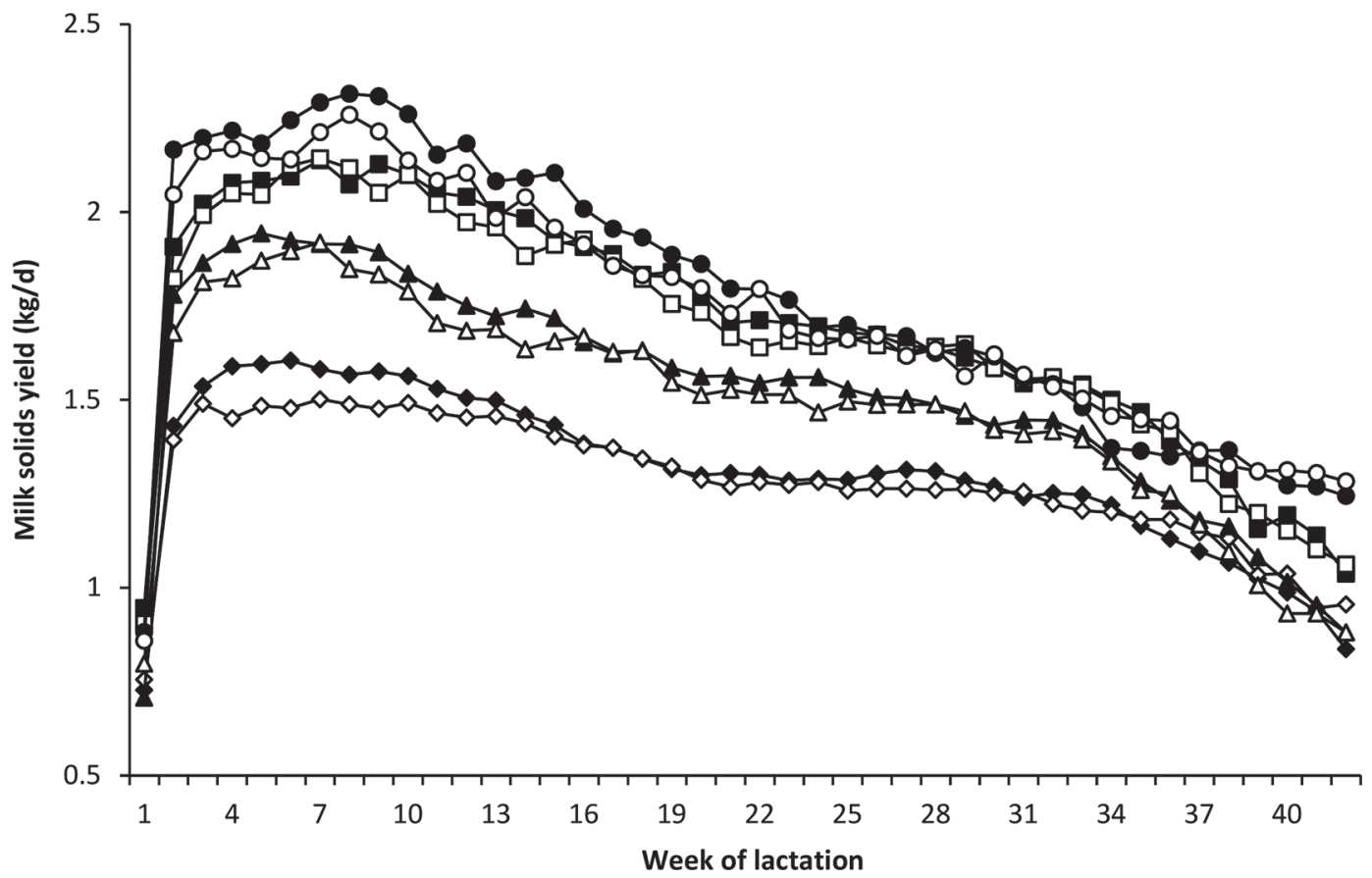

Figure 7. The effect of cow genetic group (elite = high Economic Breeding Index; NA = national average Economic Breeding Index) and parity number on daily milk solids yield for each week of lactation. $\bullet=$ elite, parity $4 ; \bigcirc=$ NA, parity $4 ; \boldsymbol{\square}=$ elite, parity 3 ; $\square=$ NA, parity $3 ; \boldsymbol{\Lambda}=$ elite, parity $2 ; \Delta=\mathrm{NA}$, parity $2 ; \diamond=$ elite, parity $1 ; \diamond=\mathrm{NA}$, parity 1 .

persistency of lactation. This is of potential concern, particularly in the context of intensive grazing systems, with increased energy requirements in peak lactation occurring in tandem with the initiation of the compact breeding period. Furthermore, there was no evidence of improved efficiency of feed utilization (from additional concentrate supplementation or increased herbage supply) in the elite cows. Therefore, the results suggest that a more precise selection for milk production, per-

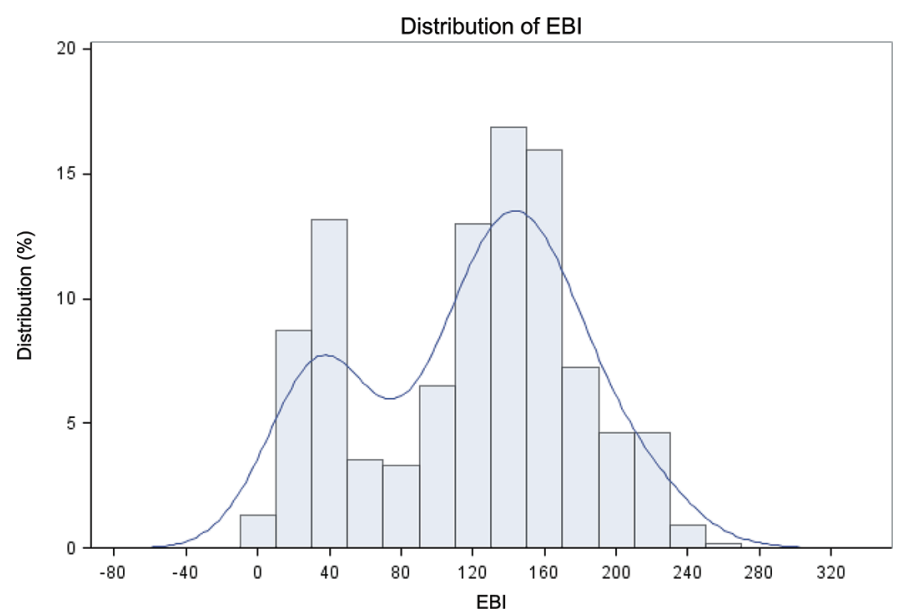

Figure 8. The distribution of Economic Breeding Index (EBI) value among animals that participated in the study. haps incorporating increased persistency and improved feed utilization, may further advance the superiority of elite animals in the future.

\section{CONCLUSIONS}

The results highlight the success of the Irish national breeding program, and EBI, to deliver production performance consistent with the national breeding objec-

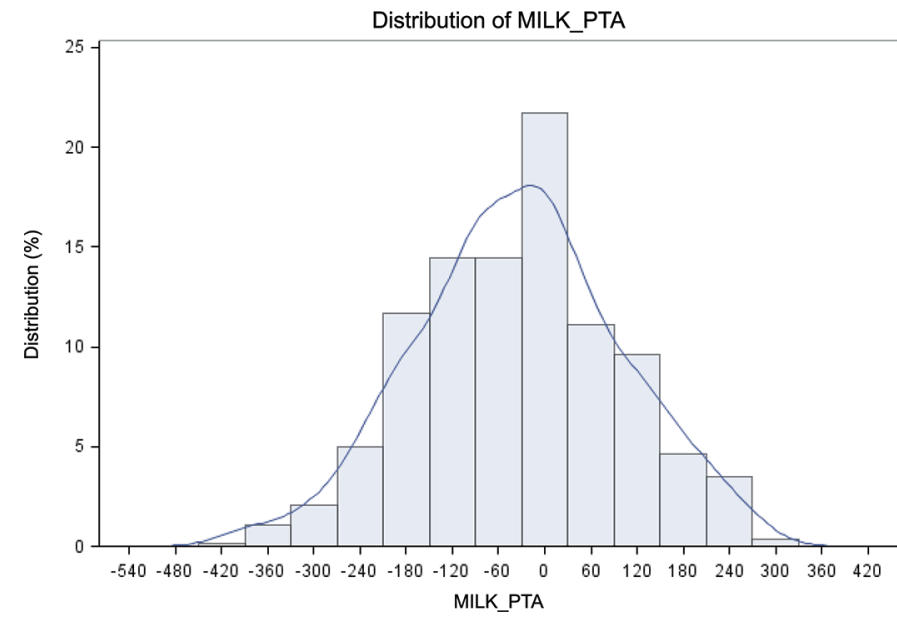

Figure 9. The distribution of predicted transmitting ability (PTA) value for milk yield among animals that participated in the study. 
tive: lower milk volume with higher fat and protein content, tending toward higher milk solids yield. Furthermore, the robustness of elite cows has been illustrated in terms of their consistency of performance over FT ranging from slight restriction to generous feeding. However, consideration of more precise selection for milk production incorporating increased persistency and improved feed utilization may further advance the superiority of high-EBI cows.

\section{ACKNOWLEDGMENTS}

The technical assistance of Ricki Fitzgerald and the diligent work of the farm staff at the Dairygold Research Farm (Teagasc, Animal and Grassland Research and Innovation Centre, Moorepark, Fermoy, Co. Cork, Ireland) are gratefully acknowledged. The authors acknowledge the contribution of the Irish Cattle Breeding Federation (Bandon, Co. Cork, Ireland) for providing access to the database for the establishment of this study and for providing the Economic Breeding Index and predicted transmitting ability values on the animals used in this study.

\section{REFERENCES}

Bargo, F., L. D. Muller, E. S. Kolver, and J. E. Delahoy. 2003. Invited review: Production and digestion of supplemented dairy cows on pasture. J. Dairy Sci. 86:1-42.

Berry, D. P., E. Wall, and J. E. Pryce. 2014. Genetics and genomics of reproductive performance in dairy and beef cattle. Animal $8: 105-121$

Breen, J., M. Wallace, S. Crosse, and D. O'Callaghan. 2007. A New Direction for the Payment of Milk: Technological and Seasonality Considerations in Multiple Component Milk Pricing of Milk (Liquid and Manufacturing) for a Diversifying Dairy Industry. Teagasc, Oak Park, Carlow, Ireland.

Buckley, F., P. Dillon, S. Crosse, F. Flynn, and M. Rath. 2000a. The performance of Holstein Friesian dairy cows of high and medium genetic merit for milk production on grass-based feeding systems. Livest. Sci. 64:107-119.

Buckley, F., P. Dillon, M. Rath, and R. F. Veerkamp. 2000b. The relationship between genetic merit for yield and live weight, condition score, and energy balance of spring calving Holstein Friesian dairy cows on grass based systems of milk production. J. Dairy Sci. 83:1878-1886.

Buckley, F., C. Holmes, and M. G. Keane. 2005. Genetic characteristics required in dairy and beef cattle for temperate grazing systems. Utilisation of grazed grass in temperate animal systems. Pages 61-79 in Proceeding of a Satellite Workshop of the XXth International Grassland Congress. J. H. Murphy, ed. Wageningen Academic Publishers, Wageningen, the Netherlands.

Coffey, E. L., L. Delaby, C. Fleming, K. M. Pierce, and B. Horan. 2018. Multi-year evaluation of stocking rate and animal genotype on milk production per hectare within intensive pasture-based production systems. J. Dairy Sci. 101:2448-2462.

Coffey, E. L., B. Horan, R. Evans, and D. Berry. 2016. Milk production and fertility performance of Holstein, Friesian, and Jersey purebred cows and their respective crosses in seasonal-calving commercial farms. J. Dairy Sci. 99:5681-5689.

Coleman, J., K. M. Pierce, D. P. Berry, A. Brennan, and B. Horan 2010. Increasing milk solids production across lactation through genetic selection and intensive pasture-based feed system. J. Dairy Sci. 93:4302-4317.

Dekkers, J., J. Jamrozik, J. Ten Hag, L. Schaeffer, and A. Weersink. 1996. Genetic and economic evaluation of persistency in dairy cattle. Interbull Bull. 12:97-102.

Delaby, L., F. Buckley, N. McHugh, and F. Blanc. 2018. Robust animals for grass based production systems. Sustainable meat and milk production from grasslands. Pages 389-400 in Proc. 27th General Meeting of the European Grassland Federation, Cork, Ireland. European Grassland Federation, Zürich, Switzerland.

Dillon, P. S. Crosse, G. Stakelum, and F. Flynn. 1995. The effect of calving date and stocking rate on the performance of springcalving dairy cows. Grass Forage Sci. 50:286-299.

Dillon, P., T. A. Hennessy, L. Shalloo, F. Thorne, and B. Horan. 2008. Future outlook for the Irish dairy industry: A study of international competitiveness, influence of international trade reform and requirement for change. Int. J. Dairy Technol. 61:16-29.

Erb, R. E., M. M. Goodwin, R. A. Morrisson, and A. O. Shaw. 1952 Lactation studies. I. Effect of gestation. J. Dairy Sci. 35:224-233.

Evans, R. D., F. Buckley, P. Dillon, and R. F. Veerkamp. 2002. Genetic parameters for production and fertility in spring-calving Irish dairy cattle. Isr. J. Agric. Res. 41:43-54.

Evans, R. D., M. Wallace, L. Shalloo, D. J. Garrick, and P. Dillon. 2006. Financial implications of recent declines in reproduction and survival of Holstein-Friesian cows in spring-calving Irish dairy herds. Agric. Syst. 89:165-183.

Friggens, N. C., F. Blanc, D. P. Berry, and L. Puillet. 2017. Deciphering animal robustness: A synthesis to facilitate its use in livestock breeding and management. Animal 11:2237-2251.

Geary, U., N. Lopez-Villalobos, D. J. Garrick, and L. Shalloo. 2010. Development and application of a processing model for the Irish dairy industry. J. Dairy Sci. 93:5091-5100.

Hanrahan, L., A. Geoghan, M. O’Donovan, V. Griffith, E. Ruelle, M. Wallace, and L. Shalloo. 2017. PastureBase Ireland: A grassland decision support system and national database. Comput. Electron. Agric. 136:193-201.

Heins, B. J., and L. D. Hansen. 2012. Short communication: Fertility, somatic cell score, and production of Normande $\times$ Holstein, Montbéliarde $\times$ Holstein, and Scandinavian Red $\times$ Holstein crossbreds versus pure Holsteins during their first 5 lactations. J. Dairy Sci. 95:918-924.

Hennessy, T., and B. Moran. 2016. Teagasc National Farm Survey. Agricultural Economics and Farm Surveys Department, Rural Economy and Development Programme, Teagasc, Athenry, Co. Galway, Ireland.

Holmes, C., I. Brookes, D. J. Garrick, D. D. S. Mackenzie, T. Parkinson, and G. F. Wilson. 2002. Milk Production from Pasture Principles and Practices. Masse University, Palmerstown North, New Zealand.

Horan, B., P. Dillon, D. P. Berry, P. O'Connor, and M. Rath. 2005a. The effect of strain of Holstein-Friesian, feeding system and parity on lactation curves characteristics of spring-calving dairy cows. Livest. Prod. Sci. 95:231-241.

Horan, B., P. Dillon, P. Faverdin, L. Delaby, F. Buckley, and M. Rath. 2005b. The interaction of strain of Holstein-Friesian cows and pasture-based feed systems on milk yield, body weight, and body condition score. J. Dairy Sci. 88:1231-1243.

Hutchinson, I. A., L. Shalloo, and S. T. Butler. 2013. Expanding the dairy herd in pasture-based systems: The role for sexed semen use on virgin heifers. J. Dairy Sci. 96:1312-1322.

ICBF (Irish Cattle Breeding Federation). 2016a. Annual report 2016 Accessed Dec. 12, 2017. https://www.icbf.com/wp/wp-content/ uploads/2013/07/Annual-Report-2016.pdf.

ICBF (Irish Cattle Breeding Federation). 2016b. Phenotypic trends in dairy. Accessed Jul 25, 2018. https://www.icbf.com/wp/?p=6939.

ICBF (Irish Cattle Breeding Federation). 2017. Update to economic values in the EBI. Accessed Jan. 20, 2018. https://www.icbf.com/ $\mathrm{wp} / \mathrm{p}=9695$.

ICBF (Irish Cattle Breeding Federation). 2018a. Introduction of the test day model in dairy evaluations. Accessed Jan. 12, 2018. https: //www.icbf.com/wp/?p=9930. 
ICBF (Irish Cattle Breeding Federation). 2018b. The role of the DAIRY G€N€ IR€LAND Programme. Accessed Jan. 26, 2018. https://www.icbf.com/wp/?p=9750.

Kearney, J. F., C. Costello, N. Kilrane, M. McCarthy, and A. R. Cromie. 2018. The role of national progeny testing programmes to collect phenotypes for dairy and beef cattle evaluations in the genomics era. Page 877 in Proceedings of the World Congress on Genetics Applied to Livestock Production, Auckland, New Zealand. Genetic Gain-Genotyping and Phenotyping Strategies.

Kellaway, R., and S. Porta. 1993. Feeding Concentrate Supplements for Dairy Cows. Dairy. Res. Dev. Corp., Melbourne, Australia.

Kennedy, J., P. Dillon, L. Delaby, P. Faverdin, G. Stakelum, and M. Rath. 2003. Effect of genetic merit and concentrate supplementation on grass intake and milk production with Holstein Friesian dairy cows. J. Dairy Sci. 86:610-621.

Matukumalli, L. K., C. T. Lawlay, R. D. Schnabel, J. F. Taylor, M. F. Allan, M. P. Heaton, J. O'Connell, S. S. Moore, T. P. Smith, and T. S. Sonstegard. 2009. Development and characterization of a high density SNP genotyping assay for cattle. PLoS One 4:e5350.

McCarthy, B. L. Delaby, K. M. Pierce, F. Journot, and B. Horan. 2011. Meta-analysis of the impact of stocking rate on the productivity of pasture-based milk production systems. Animal 5:784-794.

McCarthy, S., D. P. Berry, P. Dillon, M. Rath, and B. Horan. 2007. Influence of Holstein-Friesian strain and feed system on body weight and body condition score lactation profiles. J. Dairy Sci. 90:1859-1869.

Meuwissen, T. H. E., B. J. Hayes, and M. E. Goddard. 2001. Prediction of total genetic value using genome-wide dense marker maps. Genetics 157:1819-1829.

Miglior, F., B. L. Muir, and B. J. Van Doormaal. 2005. Selection indices in Holstein cattle of various countries. J. Dairy Sci. 88:12551263.

Morgan, D., G. Stakelum, and J. Dwyer. 1989. Modified neutral detergent cellulase digestibility procedure for use with the "Fibertec" system. Isr. J. Agric. Res. 28:91-92.

O'Donovan, M. 2000. The relationship between the performance of dairy cows and grassland management on intensive dairy farms in Ireland. PhD Thesis. University College Dublin, Ireland.

O'Brien, B., S. Crosse, and P. Dillon. 1996. Effects of offering a concentrate or silage supplement to grazing dairy cows in late lactation on animal performance and on milk processability. Ir. J. Agric. Food Res. 35:113-125.

O'Donovan, M., E. Lewis, and P. O'Kiely. 2011. Requirements of future grass-based ruminant production systems in Ireland. Ir. J. Agric. Food Res. 50:1-21.

O'Sullivan, M., S. McParland, K. M. Pierce, K. O'Sullivan, and F. Buckley. 2018. The effect of Economic Breeding Index and feeding treatment on $305 \mathrm{~d}$ production and lactation profile. Sustainable meat and milk production from grasslands. Pages 479-481 in Proc. 27th General Meeting of the European Grassland Federation, Cork, Ireland. European Grassland Federation, Zürich, Switzerland.

Olori, V. E., S. Brotherstone, W. Hill, and B. McGuirk. 1997. Effect of gestation stage on milk yield and composition in Holstein Friesian dairy cattle. Livest. Sci. 52:167-176.

Olori, V. E., and P. J. Galesloot. 1999. Projection of partial lactation records and calculation of 305-day yields in the Republic of Ireland. Interbull Bull. 22:149-154.
Patton, D., K. M. Pierce, and B. Horan. 2016. Effect of stocking rate on milk and pasture productivity and supplementary feed use for spring calving pasture fed dairy systems. J. Dairy Sci. 99:59045915.

Ramsbottom, G., A. R. Cromie, B. Horan, and D. P. Berry. 2012. Relationship between dairy cow genetic merit and profit on commercial spring calving dairy farms. Animal 6:1031-1039.

Roche, J. R., D. P. Berry, A. Bryant, C. Burke, S. T. Butler, P. Dillon, D. Donaghy, B. Horan, K. Macdonald, and K. Macmillan. 2017. A 100-year review: A century of change in temperate grazing dairy systems. J. Dairy Sci. 100:10189-10233.

Roche, J. R. 2003. Effect of pregnancy on milk production and bodyweight from identical twin study. J. Dairy Sci. 86:777-783.

Roche, J. R., D. P. Berry, and E. S. Kolver. 2006. Holstein-Friesian strain and feed effects on milk production, body weight, and body condition score profiles in grazing dairy cows. J. Dairy Sci. 89:3532-3543.

Samuels, M. L. 1993. Simpson's paradox and related phenomena. J. Am. Stat. Assoc. 88:81-88.

SAS Institute Inc. 2017. User's Guide: Statistics. Version 9.4. SAS Institute Inc., Cary, NC.

Simm, G. 1998. Genetic Improvement of Cattle and Sheep. CABI, Wallingford, UK.

Snijders, S. E., P. Dillon, K. O'Farrell, M. Diskin, A. Wylie, D O'Callaghan, M. Rath, and M. Boland. 2001. Genetic merit for milk production and reproductive success in dairy cows. Anim. Reprod. Sci. 65:17-31.

Spelman, R. J., B. J. Hayes, and D. P. Berry. 2013. Use of molecular technologies for the advancement of animal breeding: Genomic selection in dairy cattle populations in Australia, Ireland and New Zealand. Anim. Prod. Sci. 53:869-875.

Steinfeld, H., and J. Mäki-Hokkonen. 1995. A classification of livestock production systems. World Anim. Rev. 84-85:83-94.

Tyrrell, H. F., and J. Reid. 1965. Prediction of the energy value of cow's milk. J. Dairy Sci. 48:1215-1223.

Van Soest, P. J., J. B. Robertson, and B. A. Lewis. 1991. Methods for dietary fiber, and nonstarch polysaccharides in relation to animal nutrition. J. Dairy Sci. 74:3583-3597.

Veerkamp, R. F., P. Dillon, E. Kelly, A. R. Cromie, and A. F. Groen. 2002. Dairy cattle breeding objectives combining yield, survival and calving interval for pasture-based systems in Ireland under different milk quota scenarios. Livest. Prod. Sci. 76:137-151.

Veerkamp, R. F., A. F. Groen, P. Dillon, and A. R. Cromie. 2000. Dairy breeding objective and programs for Ireland. Discussion report following phase 1: Consultancy of the industry. Lelystad report.

Washburn, S. P., and K. A. E. Mullen. 2014. Invited review: Genetic considerations for various pasture-based dairy systems. J. Dairy Sci. 97:5923-5938.

Wickham, B. W., P. R. Amer, D. P. Berry, M. Burke, S. Coughlan, A. R. Cromie, J. F. Kearney, N. Mc Hugh, S. McParland, and K. O'Connell. 2012. Industrial perspective: Capturing the benefits of genomics to Irish cattle breeding. Anim. Prod. Sci. 52:172-179.

Wilmink, J. B. M. 1987. Adjustment of lactation yield for age at calving in relation to level of production. Livest. Prod. Sci. 16:321-334. 